\title{
Planning laissez-faire: Supranational central banking and structural reforms ${ }^{\star}$
}

\author{
Benjamin Braun ${ }^{\mathrm{a}}$, Donato Di Carlo ${ }^{\mathrm{b}}$, Sebastian Diessner ${ }^{\mathrm{c}}$, Maximilian Düsterhöft ${ }^{\mathrm{d}}$ \\ ${ }^{a}$ Max Planck Institute for the Study of Societies \\ ${ }^{b}$ European University Institute and Max Planck Institute for the Study of Societies \\ ${ }^{c}$ European University Institute and London School of Economics \\ ${ }^{d}$ Faculty of Business and Economics, Technische Universität Dresden
}

\begin{abstract}
The impact of international economic integration on social protection is conditional on the monetary regime. This key insight of both Polanyi and Ruggie has been neglected in the Polanyi-inspired debate on the social consequences of European integration. Focusing on the European Court of Justice and the European Commission as the supranational enforcers of the legal logic of integration, the literature has paid insufficient attention to the role of the European Central Bank (ECB) as the supranational enforcer of the economic logic of integration since monetary union. While Polanyi conceptualized central banking as an institution of non-market coordination that evolved to protect the domestic economy from gold standard pressures, the ECB has acted as an enforcer of disembedding "euro standard" pressures vis-à-vis national labor market and welfare state institutions. Performing a mixed-methods analysis of public speeches, parliamentary hearings, central bank publications, and interviews with senior decision-makers, we provide the first comprehensive study of the ECB's advocacy of structural reforms during the period 1999-2019. Despite lacking the mandate or the authority to override national legislation, the ECB, strategically pursuing its organizational and systemic interests, pushed for structural reforms via discursive advocacy and conditionality. Our results show that Europe's prospects for Polanyian non-market coordination are determined by Frankfurt as much as by Luxembourg and Brussels.
\end{abstract}

Keywords: European Central Bank, euro area, monetary integration, labor market policy, social protection, Karl Polanyi

\footnotetext{
^This paper has benefited greatly from comments by Lucio Baccaro, Cyril Benoît, Clement Fontan, Martin Höpner, Evelyne Hübscher, Edin Ibrocevic, Erik Jones, Steven Klein, Mattia Lupi, Fritz Scharpf, Marco Simoni, Matthias Thiemann, Sotiria Theodoropoulou, and Leon Wansleben. Yannick Harksen, Marie Hillebrand, and Tu Nguyen provided excellent research assistance.
} 
"[O]nly countries which possessed a monetary system controlled by central banks were reckoned sovereign states. With the powerful Western countries this unlimited and unrestricted national monetary sovereignty was combined with its complete opposite, an unrelenting pressure to spread the fabric of market economy and market society elsewhere."

-Karl Polanyi, 1944, p. 261

"EMU has made it even more urgent to improve the flexibility of labor and goods markets. ... it would very likely be the wrong answer if governments were to try to create a 'social union,' harmonizing social security systems and standards at a very high level. The ECB will continue to cajole governments into implementing necessary and long overdue reforms."

-Willem F. Duisenberg, 1999, p. 188

\section{Introduction}

The European Commission's slogan of "a Europe that protects", introduced in 2019, subtly diverges from the Treaty of Rome's commitment to "proper social protection." This is no accident. The euro area debt crisis accelerated labor market deregulation and welfare state retrenchment, and the idea of a "Social Europe" has been declared "dead." ${ }^{1}$ At the same time, and particularly among those most affected by by these developments, protectionist and nationalist sentiments have been on the rise. ${ }^{2}$ Brussels watchers have read "a Europe that protects" as a bellwether of a new, non-liberal politics of protection. ${ }^{3}$

Students of the tension between social protection and international economic integration have long been interested in the European Union (EU) as a unique case combining high levels of protection with full "globalization in the strict sense of the word", namely unrestricted competition for capital, goods and services. ${ }^{4}$ A large section of this literature operates within the theoretical framework of Karl Polanyi's The Great Transformation. ${ }^{5}$ From a Polanyian perspective, the fundamental question is whether the EU's supranational institutions act as the "prime mover in the move to a market society" or as the "active agent of the countermovement." 6 Most thoroughly scrutinized in this regard-notably in this journal-has been the European Court of Justice (ECJ). Caporaso

\footnotetext{
${ }^{1}$ Crespy and Menz, 2015, p. 182. See also Streeck, 2019, p. 139.

${ }^{2}$ Broz et al., 2021; Walter, 2021.

${ }^{3}$ Economist, 2019.

${ }^{4}$ Scharpf, 1997, pp. 18-19.

${ }^{5}$ Polanyi, 2001. Other approaches to the political economy of social protection in the EU have focused on the distinction between negative and positive integration - see Scharpf, 1999 - and on the interaction between different models of capitalism and welfare states, see Höpner and Schäfer, 2010; Streeck, 1995. ${ }^{6}$ Caporaso and Tarrow, 2009, p. 597.
} 
and Tarrow have argued that, by following a legal logic of integration and gradually enforcing an array of social rights applying to EU citizens, the ECJ has re-embedded the European Common Market. ${ }^{7}$ In Höpner and Schäfer's contrasting analysis, the ECJ's jurisprudence has advanced a "market-enhancing" form of integration, thus contributing to the disembedding of national economies. ${ }^{8}$ Similarly, Crespy and Menz have described the EU's second supranational body, the European Commission, as a "political entrepreneur" that has "all but [abandoned] traditional social democratic goals of decommodification of labour [sic]." 9

What has been strikingly absent from this literature on the social potential of European economic integration is European monetary integration. ${ }^{10}$ This oversight is surprising, first, because Polanyi treats both labor and money as "fictitious commodities," and both trade unions and central banks as institutions of non-market coordination produced by the "countermovement." 11 Secondly, the impact of international economic integration on social protection is mediated by the monetary regime. ${ }^{12}$ By irrevocably fixing their exchange rates, member states relinquished a crucial tool of macroeconomic adjustment. Pressures to commodify labor in adjustment to a fixed-exchange rate regime - a central theme of The Great Transformation - thus re-emerged under European Economic and Monetary Union (EMU). The strictures of the euro considerably amplified the economic logic of integration relative to the legal and political logics expressed through the ECJ and the Commission, respectively. ${ }^{13}$ With the introduction of the euro in 1999, this economic logic of integration found its institutional expression in the European Central Bank (ECB). Since then, the relationship between economic integration and social protection has been shaped in Frankfurt as much as in Brussels and Luxembourg.

This paper presents the first comprehensive study of the ECB's advocacy for structural reforms. The ECB defined structural reforms, in strikingly Polanyian terms, as policies

\footnotetext{
${ }^{7}$ Caporaso and Tarrow, 2009.

${ }^{8}$ Höpner and Schäfer, 2012. See also Weingast, 1995, who characterized the European polity as a form of market-preserving federalism in which the remaining "market-embedding institutions" at the national level come under liberalization pressure from supranational institutions. See also Garrett et al., 1998.

${ }^{9}$ Crespy and Menz, 2015, p. 756. See also Andor, 2013. The Commission's role as a proponent of market-enhancing integration has been most pronounced in the field of competition policy; see Billows et al., 2021; Jabko, 2006.

${ }^{10}$ Klein, 2020.

${ }^{11}$ Polanyi, 2001, pp.75-76.

${ }^{12}$ Ruggie, 1982.

${ }^{13}$ Scharpf, 2010, 2016.
} 
that "change the fabric of an economy, the institutional and regulatory framework in which businesses and people operate." 14 This advocacy constitutes a puzzle: The ECB lacks both a mandate and the legal means to shape labor market and social policies at the member-state level. Pushing to "change the fabric" of societies therefore entails significant reputational risks. Why, then, did the ECB chose to push for structural reforms? Our explanatory framework places the emphasis on the ECB's organizational (credibility and legitimacy) and systemic (survival of the euro) interests. In pursuing those interests, the ECB strategically adjusted the method and content of its structural reform advocacy to fit the economic and political context. During the first decade the ECB's power resources were largely limited to its epistemic authority, wielded in its communicative (public) and coordinative (behind the scenes) discourse. In the wake of the euro area debt crisis, the ECB acquired the power - shared with the Commission and the International Monetary Fund (IMF) - to impose and enforce policy conditionality.

Our analysis, while drawing on Polanyi, fills an important gap in Polanyian thinking on the political economy of central banking. According to Polanyi, national central banking evolved as an expression of the countermovement to the commodification of money under the international gold standard. Whereas Polanyi said little about potential conflicts between non-market coordination in the domain of money (central banks) and social protection in the domain of labor (social policies and trade unions), this conflict subsequently moved to the very center of macroeconomic governance. A large literature has since studied the interaction between national central banks and national labor market policies and wage-setting actors. ${ }^{15}$ However, the institutional setting of this interaction changed dramatically with EMU, which established a supranational monetary regime with its own supranational central bank. From the beginning, heterogeneous labor market institutions and social policies threatened divergent national inflation developments, which clashed with the ECB's one-size-fits-all monetary policy. ${ }^{16}$ Whereas Polanyi would have expected a central bank to protect national economies from the disembedding pressures of the monetary regime, the ECB has instead embodied these very pressures, acting as

\footnotetext{
${ }^{14}$ ECB, 2017 and speech 40, Appendix Appendix B. On the evolving meanings of "structural reform" in EU discourse, see Crespy and Vanheuverzwijn, 2019.

${ }^{15}$ Hall and Franzese, 1998; Hancké, 2013; Scharpf, 1991.

${ }^{16}$ Enderlein, 2006; Scharpf, 2011; Vermeiren, 2017.
} 
a - if not the - key planner of laissez-faire in national labor markets. ${ }^{17}$

Looking beyond Europe, our analysis contributes to the literature on policy diffusion in the context of economic globalization. ${ }^{18}$ Here, national policymakers routinely encounter the problems of translating and enforcing perceived functional pressures emanating from the international level. First, policymakers seeking to conceptualize the systemic pressures of the international monetary regime are confronted with considerable "epistemic uncertainty." ${ }^{19}$ Whereas the construction of embedded liberalism was facilitated by "widespread consensus about what needed to be done," international financial liberalization created "epistemic disarray." 20 Second, where adjustment to the functional requirements of the international monetary regime requires policies of the disembedding variety, they tend to be politically difficult to implement. ${ }^{21}$ The literature on policy diffusion has emphasized the key role of international organizations in overcoming these obstacles. The IMF, guided by the "Washington Consensus," made its emergency lending conditional on governments' implementing specific structural reforms, playing the role of both translator and enforcer. ${ }^{22}$ Central banks, as the ultimate repositories of "epistemic authority" on economic matters, are uniquely positioned to play a similar role at the domestic level. ${ }^{23}$ Our analysis reveals that in the euro area, the role of translator and - to a lesser but significant extent - enforcer of perceived functional pressures was assumed by the ECB. For instance, we show that the ECB identified - and sought to counter via structural reforms and public-sector wage restraint - the diverging trend in unit labor costs as early as 2005, years before the European Commission. ${ }^{24}$

\footnotetext{
${ }^{17}$ This contrasts with Caporaso and Tarrow's view of the ECJ as a technocratic bulwark against "the market-making policies of the Single European Act and the Treaty on the European Union." See Caporaso and Tarrow, 2009, pp. 597-598. For a study of a local Polanyian countermovement against Troika-imposed reforms, see Kentikelenis, 2018.

${ }^{18}$ Dobbin et al., 2007.

${ }^{19}$ Taking this concept from Nelson and Katzenstein, 2014, p. 362, we emphasize its particular relevance in international monetary affairs. For instance, prior to Great Britain's suspension of the gold standard in 1931, "most policy-makers did not know that they even "could' leave gold"; see Morrison, 2016, p. 176. On central banks confronting epistemic uncertainty in the context of the emerging Eurodollar market, see Braun et al., 2020, pp. 10-13.

${ }^{20}$ Ruggie, 1995, pp. 525-526; Ikenberry, 1992

${ }^{21}$ Walter, 2013, pp. 42-49.

${ }^{22}$ Kentikelenis and Babb, 2019. On the impact of IMF programs on labor market deregulation, see Reinsberg et al., 2019. Another influential advocate of structural labor market reforms has been the Organization for Economic Co-operation and Development (OECD), see Baccaro and Rei, 2007; Keohane, 1978.

${ }^{23}$ On European central bankers as an "epistemic community", see Verdun, 1999. On the ECB's "hyperscientization", see Mudge and Vauchez, 2016.

${ }^{24}$ Note that our argument does not imply that the ECB was "right". Indeed, critics have long argued
} 
The paper proceeds as follows. Section 2 introduces the Polanyian concept of nonmarket coordination and sketches the evolution of the labor-money nexus from the gold standard to the euro standard. Section 3 presents a theory of why (motivation) and how (instruments) the ECB took such an active approach to a policy area outside of its formal mandate. Section 4 elaborates on data and methodology. Sections 5 and 6 examine the ECB's advocacy for structural reforms from 1999 until 2019. We conclude by discussing our findings' broader implications.

\section{Polanyi and (supra)national central banking}

Karl Polanyi considered the commodification of the factors of production-land, labor, and money - to be the defining feature of market society. The commodification of money reached its highest point in the international gold standard, under which countries committed themselves to maintaining fixed exchange rates by pegging their currencies to the price of gold. The effect was the unconditional subordination of "the stability of incomes and employment to the stability of the currency." ${ }^{25}$ Disembedding these "fictitious commodities" from traditional modes of coordination and subjecting them to the market mechanism was a highly conflictual process that required a strong state: "laissez-faire was planned." 26

In response to the disembedding of labor and money, a "countermovement" pushed for greater social protection. ${ }^{27}$ Trade unions, collective bargaining, and social policies became institutionalized as forms of "non-market coordination" in the domain of labor. In the domain of money, central banking emerged as the key institution of non-market coordination: "a device developed for the purpose of offering protection without which the market would have destroyed its own children." 28 Indeed, central banking as a tool of macroeconomic stabilization "developed as a response to the pressure emanating from the gold standard." 29 To facilitate internal adjustment and protect financial and eco-

that structural labor market reforms may exacerbate problems arising from international economic integration; see Baccini et al., forthc. Solow, 1998.

${ }^{25}$ Polanyi, 2001, p. 235. See also Mundell, 1963 and Ruggie, 1982, p. 389.

${ }^{26}$ Polanyi, 2001, p. 147.

${ }^{27}$ Polanyi, 2001, p. 136. Here we draw on Klein's discussion of Polanyi's understanding of trade unions and central banks. See Klein, 2020.

${ }^{28}$ Polanyi, 2001, p. 201. For a discussion of Polanyi's analysis of $19^{\text {th }}$-century central banking as an institution of non-market coordination, see Knafo, 2013, pp. 30-32.

${ }^{29}$ Knafo 2013, p. 152 
Table 1: Non-market coordination at the national level, gold standard versus EMU

\begin{tabular}{lll}
\hline $\begin{array}{l}\text { Institutions of non-market } \\
\text { coordination }\end{array}$ & Gold standard & EMU \\
\hline $\begin{array}{l}\text { Organized labor and collective } \\
\text { bargaining }\end{array}$ & Weak but getting stronger & Strong but getting weaker \\
National central banking & Yes (in the core countries) & No \\
\hline
\end{tabular}

nomic stability, central banks learned to use a number of instruments of non-market coordination, including last-resort lending to address liquidity problems in the financial system; accumulation and active management of foreign currency reserves during episodes of capital flight; and interest rate policy to steer capital flows, credit creation, and thus macroeconomic conditions. ${ }^{30}$

The international gold standard was thus characterized by a double asymmetry, with striking parallels to the euro area (see Table 1). First, non-market coordination was asymmetric between the domains of money and labor. Whereas central banks provided substantial protection for financial investors, there were few institutional impediments to the price mechanism in the labor market. Under the classical gold standard in particular, absent or weak political and industrial democracy meant that workers bore the brunt of the burden of adjustment: "Calling for lower wages was the discourse of the gold standard." ${ }^{31}$ The second asymmetry concerned the distribution, between the core and the periphery, of monetary sovereignty. In the creditor countries of the core, central banks were able to deploy their instruments of non-market coordination to mitigate adjustment pressures. Debtor countries on the periphery, however, often did not have a central bank and generally lacked the means to protect themselves against disruptive capital flows. ${ }^{32}$ This defenselessness was a feature, not a bug. Creditor countries actively interfered in the political and economic institutions of debtor countries to increase the likelihood of debt repayment. ${ }^{33}$ Even in developed European economies, "Labour Parties were made to quit office "to save the currency."' 34 Laissez-faire was planned abroad, too.

\footnotetext{
$\overline{{ }^{30} \text { Bazot et al., 2019, 2020. Uncertainty }}$ as to how to use these instruments endured throughout the interwar period, see Morrison, 2016 and Simmons, 1994.

${ }^{31}$ Eichengreen and Temin, 2000, p. 192.

${ }^{32}$ Triffin, 1946. In 1900, only 18 countries had established central banks. See Capie et al., 1994, p. 6.

${ }^{33}$ Polanyi, 2001, p. 261. See Lipson, 1985.

${ }^{34}$ Polanyi, 2001, p. 237.
} 
World War II reversed the hierarchy between money and labor. Non-market coordination in the domain of money henceforth needed to be reconciled with non-market coordination in the domain of labor. ${ }^{35}$ At the heart of this "embedded liberalism" lay the Bretton Woods system of fixed but adjustable exchange rates, which prioritized national policy autonomy over international capital mobility, and full employment over sound money. ${ }^{36}$ With regard to non-market coordination, the tables had turned: whereas industrial labor was strong, collective bargaining institutionalized, and welfare states developed, central banks were subordinated to democratically elected governments. ${ }^{37}$

Following the collapse of Bretton Woods, governments, by reinstating capital mobility, created a trade-off between exchange rate stability and national autonomy in monetary policy. The European Monetary System (EMS) - in which national currencies were fixed but adjustable via politically negotiated re-alignments - sought to combine moderate exchange rate stability, moderate capital mobility, and moderate national policy autonomy - a tenuous midpoint in Mundell's trilemma. ${ }^{38}$ The EMS allowed for the continued co-existence of non-market coordination of money and labor, albeit at the cost of exchange rate instability and conflicts between governments over currency realignments. ${ }^{39}$ European monetary integration eliminated both instruments of non-market coordination. First, the creation of the European Central Bank severed the relationship between national independent central banks and coordinated wage setting in the hard currency countries. ${ }^{40}$ Second, the single currency removed the option of exchange rate devaluation for soft currency countries. ${ }^{41}$

Comparing EMU to the international gold standard through a Polanyian lens thus highlights one key parallel and two fundamental differences. ${ }^{42}$ The parallel lay in the political choice to prioritize fixed exchange rates, price stability, and full capital mobility over national policy autonomy. EMU and the gold standard thus occupy the same position

\footnotetext{
${ }^{35}$ Ruggie, 1982. See also Klein, 2020.

${ }^{36}$ Ruggie, 1982.

${ }^{37}$ Goodman, 1992.

${ }^{38}$ Bordo and James, 2019, p. 250. Otmar Issing, then the ECB's chief economist, described the EMS as "a prime example of policymakers' refusal to succumb to (or failure to acknowledge) the unpleasant logic of the trilemma." See Issing, 2006.

${ }^{39}$ Höpner and Spielau, 2018.

${ }^{40}$ Hall and Franzese, 1998; Scharpf, 1991, pp. 266-267

${ }^{41}$ Scharpf, 2016.

${ }^{42}$ For earlier Polanyian analyses of EMU, see Holmes, 2014; Klein, 2020; McNamara et al., 2015; Seccareccia and Correa, 2017.
} 
in Mundell's trilemma. ${ }^{43}$ Indeed, while both regimes represent "extreme forms of fixed exchange rates," EMU goes further still by eliminating national currencies altogether. ${ }^{44}$ The first difference was that unlike the gold standard, the euro standard coexisted with strong embedding institutions (such as trade unions, collective bargaining, and welfare states) at the national level. ${ }^{45}$ The second difference was that the central bank was not a national-level institution in charge of a national currency, but a supranational monetary authority in charge of a supranational currency.

In the domain of money, the ECB acted in a Polanyian fashion during and after the 2008 financial crisis, using its lender-of-last-resort powers to backstop and protect the financial system. By contrast, EMU set up a clash between non-market coordination of money and non-market coordination of labor. That this clash has put pressure on member states to liberalize labor markets, cut back the power of organized labor, and decentralize wage bargaining systems is well documented in the literature on industrial relations and labor market policy. ${ }^{46}$ What both these studies and the broader literature on the social policy consequences of European integration have neglected, however, is the agency of the European Central Bank when it came to translating, and subsequently enforcing, the functional pressures of the supranational monetary regime.

\section{Theorizing the ECB: agency and instruments}

Why, given the potential reputational costs, would the ECB push for the disembedding of national economies via structural labor market reforms? And how, given its lack of formal authority, could it do so?

\subsection{Why? Organizational and systemic interests}

The ECB's persistent advocacy of structural reforms presents a puzzle. On one hand, labor market and social policies in EMU member states impact the ECB's ability to achieve

\footnotetext{
${ }^{43}$ Bordo and James, 2019.

${ }^{44}$ Eichengreen and Temin, 2010, p. 370. Adjusting the exchange rate remained a possibility under the gold standard but is impossible for EMU member states. Note, however, that TARGET2 - the Eurosystem's payment system - provides a stabilizing "insurance mechanism" that was not available under the gold standard. See Schelkle, 2017, ch. 9 and Bazot et al., 2020.

${ }^{45}$ Höpner and Schäfer, 2010; Scharpf, 2010.

${ }^{46}$ On labor market deregulation, see Baccaro and Howell, 2017; Bulfone and Tassinari, 2020 and Simoni and Vlandas, 2020. On trade union disempowerment, see Rathgeb and Tassinari, 2020. On wage bargaining decentralization and internal devaluation, see Bulfone and Afonso, 2020; Van Gyes and Schulten, 2015.
} 
its mandated price-stability goal but fall outside the scope of its delegated authority. Advocating, let alone using its powers to enforce structural reforms thus constitutes a form of overreach that involves a reputational cost. On the other hand, the ECB has been shown to pursue its interest with a high capacity for strategic action. ${ }^{47}$ The challenge, then, is to explain the strategic calculus behind the ECB's structural reform advocacy.

Our theory of the ECB distinguishes between organizational and systemic interests. While organizational interests suffice to explain ECB actions during good times, they are superseded, at moments of systemic crisis, by the need to do "whatever it takes" to prevent financial collapse or even the break-up of the currency.

The ECB's organizational interest has two dimensions, defined by its interactions with two main audiences. ${ }^{48}$ Central banks seek to establish and sustain credibility visà-vis market audiences, the conditions for which are their independence (performed by upholding policy commitments against government pressure) and their epistemic authority (performed via "investment in scientific prestige and scholarly research"). ${ }^{49}$ At the same time, central banks seek to establish and sustain legitimacy vis-à-vis political audiences, notably their government principals and the broader public. ${ }^{50}$ Here, they must balance output-legitimacy (achieving mandated policy goals) and throughput-legitimacy (acting within the scope of established rules and procedures that underpin the organization's authority). ${ }^{51}$

Organizational interests cannot, however, explain central bank behavior during crisis periods. Systemic crises invariably force central banks to step in as lenders of last resort, without regard to the consequences for their credibility or legitimacy. This distinction between normal times and crisis times is well established in the broader literature on finance and central banking. Indeed, Polanyi's analysis of adjustment under the international gold standard emphasized that finance "governs by panic." 52 The distinction applies with particular force to the ECB, which in a crisis confronts the possibility of a break-up of the currency area (such as "Grexit"). Avoiding such systemic breakdown-and its own

\footnotetext{
${ }^{47}$ See, for instance, Heldt and Mueller, 2020; Henning, 2016; Howarth, 2004.

${ }^{48}$ On central banks and their audiences, see Lohmann, 2003.

${ }^{49}$ Mudge and Vauchez, 2016, p. 148. On the interplay of credibility and independence, see Bodea and Hicks, 2015; Keefer and Stasavage, n.d.

${ }^{50}$ On central banks' responsiveness to broader public legitimacy concerns, see Dietsch, 2020; Moschella et al., 2020.

${ }^{51}$ Scharpf, 1999; Schmidt, 2016, 2020.

${ }^{52}$ Polanyi, 2001, p. 238. See Woodruff, 2016.
} 
obsolescence-becomes an overriding "grim necessity" for the ECB. ${ }^{53}$ Several of its key decisions cannot be explained by organizational interests. Most notably, the ECB was fully aware that its announcement of Outright Monetary Transactions in mid-2012-Mario Draghi's famous "whatever it takes" statement - and its launch of quantitative easing in early 2015 would lead to political backlash and protracted legal battles. ${ }^{54}$ Thus, wile organizational interests - credibility and legitimacy - suffice to explain the ECB's enabling advocacy of structural reforms during the period 1999-2009, they were subsequently superseded by the systemic imperative to preserve the very integrity of the euro area. The ECB did what it thought it took to "save the currency." 55

\subsection{How? The ECB's instruments as translator and enforcer}

The supremacy of EU law allows the European Court of Justice to use treaty law on individual rights to advance liberalization in areas such as labor law and taxation. By contrast, the ECB lacks the authority to issue binding regulations to override national law. It does, however, possess other means to exercise political pressure on national governments to implement deregulatory policies. Acting as a translator of the functional pressures of the monetary regime, the ECB can leverage its epistemic authority to reduce epistemic uncertainty and create a discursive environment conducive to structural reforms. On the other hand, the ECB can use its unique institutional position to act as an enforcer of structural reforms. ${ }^{56}$ The five instruments available to the ECB in fulfilment of these roles are summarized in Table 2 .

The ECB's role as translator of functional pressures rests on its epistemic authority, which allows it "to persuade other actors of the cognitive validity and/or normative value" of its economic policy ideas ("power through ideas"). ${ }^{57}$ The ECB exercises this ideational power via both its "communicative" and its "coordinative" discourse. ${ }^{58}$ Through speeches and publications, it provides economic justifications for structural reforms, which other policymakers can resort to in order to bolster their own epistemic authority. Members of

\footnotetext{
53 Dyson, 2013.

${ }^{54}$ On the "judicialisation of EMU politics", see Saurugger and Fontan, 2019. See also de Boer and van't Klooster, 2020.

${ }^{55}$ Polanyi, 2001, p. 237.

${ }^{56}$ The ECB's lack of direct legal authority means that we cannot establish a direct causal link between the ECB's preferences and the implementation of structural reforms at the member-state level.

${ }^{57}$ Carstensen, Martin B. and Schmidt, Vivien A., 2016. On the role of ideas for the ECB's monetary policy, see Ferrara, 2020.

${ }^{58}$ Schmidt, 2008, pp. 304-305.
} 
Table 2: ECB agency disaggregated

\begin{tabular}{llll}
\hline Role & Instrument & Power resource & Mechanism \\
\hline $\begin{array}{l}\text { Translator of } \\
\text { monetary regime } \\
\text { pressures }\end{array}$ & $\begin{array}{l}\text { Communicative } \\
\text { discourse }\end{array}$ & $\begin{array}{l}\text { Ideational power based } \\
\text { on epistemic authority }\end{array}$ & $\begin{array}{l}\text { Public rhetorical } \\
\text { pressure }\end{array}$ \\
\cline { 2 - 4 } & $\begin{array}{l}\text { Coordinative } \\
\text { discourse }\end{array}$ & $\begin{array}{l}\text { Ideational power based } \\
\text { on epistemic authority }\end{array}$ & $\begin{array}{l}\text { Moral suasion of } \\
\text { governments }\end{array}$ \\
\hline $\begin{array}{l}\text { Enforcer of } \\
\text { monetary } \\
\text { regime }\end{array}$ & Monetary policy & $\begin{array}{l}\text { Central bank } \\
\text { independence }\end{array}$ & $\begin{array}{l}\text { Non-accommodating } \\
\text { monetary policy }\end{array}$ \\
\cline { 2 - 4 } & $\begin{array}{l}\text { Informal } \\
\text { conditionality }\end{array}$ & $\begin{array}{l}\text { Structural power of the } \\
\text { lender of last resort }\end{array}$ & $\begin{array}{l}\text { Conditions attached to } \\
\text { unconventional } \\
\text { monetary policies }\end{array}$ \\
\cline { 2 - 4 } & $\begin{array}{l}\text { Formal } \\
\text { conditionality }\end{array}$ & $\begin{array}{l}\text { Structural power of } \\
\text { creditor institutions } \\
\text { (with ESM and IMF) }\end{array}$ & $\begin{array}{l}\text { Conditions attached to } \\
\text { macroeconomic } \\
\text { adjustment programs }\end{array}$ \\
\hline
\end{tabular}

the ECB's executive board can also directly engage national governments in a coordinative discourse in the context of ECOFIN council or Eurogroup meetings. The ECB's discourse is amplified further by the national central banks, which transmit its reform advocacy to the national arena through their own public interventions (see Figure A.5, Appendix A).

Central banks' discursive advocacy is most effective when accompanied by a hard monetary policy stance. ${ }^{59}$ Increasing policymakers' ability to retaliate against - or, more efficiently, to deter - "excessive" wage increases is the raison d'être of central bank independence. ${ }^{60}$ At the same time, governments deprived of the option of easing monetary policy are more likely to deregulate labor markets in order to generate growth and employment via the supply side. ${ }^{61}$

While the instruments of discursive advocacy and tight monetary policy are available to any central bank, the ECB's unique position as a supranational monetary authority affords it certain coercive powers to also enforce structural reforms in member states. ${ }^{62}$ As seen in the sovereign debt crisis, the ECB can wield the power to impose both formal and informal conditionality on national governments. Specifically, the dependence of governments and their domestic banking systems on ECB lending and bond purchases

\footnotetext{
${ }^{59}$ Rieth and Wittich, 2020.

${ }^{60}$ Hall and Franzese, 1998.

${ }^{61}$ Aklin et al., 2021.

${ }^{62}$ On the ECB's ideational and coercive instruments, see Ban, 2016.
} 
puts the central bank in a position to informally condition its support measures on the implementation of reforms. ${ }^{63}$ Finally, macroeconomic adjustment programs open the door to the ECB's direct participation in the design of conditionality agreements attached to financial assistance programs. ${ }^{64}$

\section{Data and method}

The ECB is difficult to study. The deliberations of the Governing Council are highly confidential; archival documents will be released only after 30 years. In order to overcome these obstacles, we deploy a mixed-methods research strategy that draws on as wide a range of evidence as possible. The primary data source from which we reconstruct the ECB's communicative discourse are the 1,922 public speeches the ECB delivered between 1999 and 2019. ${ }^{65}$ We applied purely quantitative methods to the full corpus and performed manual coding and reading on a sub-sample of speeches. First, we used quantitative text analysis to chart the frequency with which the ECB mentions structural reforms (Figure 1). To map the evolving context of those mentions quantitatively, a proximity measure for selected, manually defined topics is shown in Appendix Appendix B (Figure A.6; dictionaries in Table A.7). Second, we coded the ten speeches per calendar year that contain the most references to structural reforms. For each such reference we coded the goals the ECB associated with structural reforms (such as reducing unemployment and increasing competitiveness; see Table 4) and the types of policy instruments advocated (for example, higher labor market flexibility; see Table 5). We aggregated instruments aimed at strengthening the market mode of coordination into the category "disembedding reforms." Instruments that combine liberalization with measures aimed at improving workers' employability are aggregated into the category "embedded flexibilization." 66 The disaggregated view of reform instruments is presented in Appendix A (Table A.6). Finally, in order to reconstruct the ECB's motivations and intentions in greater detail, we closely read sections of speeches pertaining to structural reforms. We surveyed the vast major-

\footnotetext{
${ }^{63}$ Fontan, 2018; Sacchi, 2015; Theodoropoulou, 2016.

${ }^{64}$ Jacoby and Hopkin, 2019; Roos, 2019.

${ }^{65}$ On the increased importance of central bank speech, see Baerg, 2020. We exclude the ECB's monthly press conferences because the structural reform prescriptions contained therein are broad, brief and repetitive. Public speeches allow us to identify variation in the ECB's structural reform advocacy over time.

${ }^{66}$ Thelen, 2014. On social investment, see Hemerijck, 2017; Morel et al., 2012.
} 
ity of references to structural reforms in this manner. Particularly relevant statements are cited in the analysis below; a larger selection of quotes can be found in Appendix Appendix B.

In order to validate and contextualize our reading of the ECB's speeches, we collected and analyzed three further types of data. To understand the economic analysis underpinning the ECB's evolving stance on structural reforms, we traced the ECB's own research output on topics such as unemployment, price developments, competitiveness, and structural reforms. In order learn more about policymakers' own perceptions of key junctures, as well as on their closed-door conversations ("coordinative discourse") with finance ministers and other government officials, we conducted interviews with four former members of the ECB's Executive Board and one former finance minister (listed in Appendix Appendix C). Finally, to measure political contestation surrounding the ECB's structural reform advocacy during the post-crisis period, we collected and analyzed the questions put to the ECB president during the quarterly "Monetary Dialogue" hearings at the European Parliament. We coded all 1,240 questions asked between 2009 and 2019, of which 47 specifically addressed structural reforms (Figure 3).

\section{Critical juncture: Choice between market-shaping and market-enhancing integration}

The Maastricht Treaty delegated monetary policy to an independent, supranational central bank. The other key macroeconomic governance tools-fiscal, wage, and regulatory policy - remained, to varying degrees, under national control. The ECB thus faced an economic coordination problem. The risk-clearly perceived by contemporary observers - was that monetary integration would result in diverging unit labor costs and, in countries lacking the institutional infrastructure for wage restraint, high unemployment. ${ }^{67}$

Although not mandated to pursue an employment goal, the ECB cared deeply about unemployment, which threatened to undermine its organizational interest in achieving and maintaining output legitimacy. The two theoretically viable solutions to the coordination problem faced by supranational monetary policymakers and national wage setters are perfectly captured by Höpner and Schäfer's conceptual pair. ${ }^{68}$ Market-shaping inte-

\footnotetext{
${ }^{67}$ Boyer, 1993; Scharpf, 1991, ch. 12

${ }^{68}$ Höpner and Schäfer, 2012.
} 
gration would have entailed the "Europeanization of pay," as well as a strengthening of "social Europe" through the pan-European coordination of wage and social policy. ${ }^{69}$ This would have amounted to a re-embedding of labor at the supranational level. Marketenhancing integration, by contrast, prescribed the decentralization of collective bargaining and the deregulation of national labor markets and social systems through structural reforms. This solution amounted to reverse-engineering the disembedded national labor markets that facilitated adjustment under the international gold standard. Contemporary observers expected EMU to lead to increased cross-border coordination among trade unions, while remaining skeptical regarding the prospects for a transnational collective bargaining regime. ${ }^{70}$ As soon as it came into existence, the ECB was forced to take a position vis-à-vis these two alternative solutions.

In the context of high unemployment rates and public opinion becoming "increasingly pessimistic about the implications of EMU for employment," the Amsterdam Treaty of 1997 launched the "European Employment Strategy." 71 In order to achieve an employmentfriendly macroeconomic policy mix, trade unions advocated ex-ante coordination with the ECB and the ECOFIN Council. ${ }^{2}$ This preference received governmental support when, during its Council presidency in 1999, the German government, under the auspices of then finance minister Oskar Lafontaine, proposed a "European Employment Pact" that included a "Macroeconomic Dialogue." As noted by one of the authors of the original German proposal, the idea had been "to get social partners to agree and coordinate their wage settlements with monetary and fiscal policy." ${ }^{73}$ However, following resistance from the United Kingdom and Lafontaine's ousting from the government, a watered-down version was signed at the Cologne Council in June 1999. Convening representatives of the Council, the Commission, the ECB, and the social partners, the bi-annual Macroeconomic Dialogue was designed to "improve the conditions for a cooperative macro-economic policy mix geared to growth and employment while maintaining price stability." 74

The ECB was internally divided on the question of its involvement in the Macroe-

\footnotetext{
${ }^{69}$ On the "Europeanization of pay," see Jacobi, 1996. On "social Europe," see Leibfried and Pierson, 1992.

${ }^{70}$ Marginson and Sisson, 1998.

${ }^{71}$ Goetschy, 1999, p. 124.

72 Jacobi, 1998.

${ }^{73}$ Collignon, 2009, p. 463. For a detailed account, see EIRR, 1999.

${ }^{74}$ European Council, 1999, p. 1.
} 
conomic Dialogue. Some members of the Executive Board had "much sympathy" for the market-shaping option of ex-ante policy coordination. ${ }^{75}$ Nevertheless, concerns over the ECB's independence prevailed. ${ }^{76}$ During his first official appearance before the European Parliament, President Duisenberg announced that the Monetary Dialogue "should be clearly distinguished from any attempts to coordinate policies ex ante, so as to achieve a certain "policy mix'," as this would "decrease accountability, reduce the transparency of the policy framework for the public and increase uncertainty about policy actions, potentially threatening to destabilise the economy." 77 This choice set the stage for what would become a sustained campaign by the supranational central bank to foster marketenhancing integration.

Thus, when prompted to position itself vis-à-vis market-shaping integration versus market-enhancing integration, the ECB chose the latter. Its preference for the structuralreforms solution was conditioned by a historically specific confluence of macroeconomic ideas. Two firmly-held theoretical commitments stand out. First, the New Classical macroeconomics at the core of the "Brussels-Frankfurt consensus" put economic growth beyond the reach of macroeconomic stabilization policy. ${ }^{78}$ The ECB argued on this theoretical foundation and in direct response to the Macroeconomic Dialogue proposal that "the best contribution monetary policy can make to fostering employment growth and reducing unemployment ... is to maintain price stability." 79 Conversely, EMU's growth potential could be increased only by supply side-oriented structural reforms aimed at removing labor market rigidities. This belief in market-enhancing structural reforms as the only viable remedy to high unemployment was so prevalent among Europe's monetary policymakers that Robert Solow mocked it as "your basic European central banker's folk-theorem." 80

The second theoretical commitment was what we might call the ECB's "theory of change." In 1999, it was clear that EMU did not meet Mundell's criteria for an "Optimum Currency Area" (OCA). ${ }^{81}$ However, taking their cue from the Commission's influen-

\footnotetext{
${ }^{75}$ Interview 4, Appendix Appendix C.

${ }^{76}$ Collignon, 2009, p. 463.

${ }^{77}$ Speech 7, Appendix Appendix B.

${ }^{78}$ De Grauwe, 2006; Fitoussi and Saraceno, 2013; Jones, 2013.

${ }^{79}$ ECB, 1999, p. 31.

${ }^{80}$ Solow, 1998, p. 205. For a subsequent critique of the market-enhancing consensus view, see Baccaro and Rei, 2007.

${ }^{81}$ Mudge and Vauchez, 2016, pp. 154-155. According to OCA theory, a monetary union generates the
} 
tial "One market, one money" report, economists had formulated a variant of OCA that proved highly attractive to monetary policymakers. ${ }^{82}$ According to Frankel and Rose's "endogeneity hypothesis," the very establishment of monetary union would create an optimum currency area by forcing firms - and wage setters - to adjust to the competitive conditions of the single market. ${ }^{83}$ At the ECB, policymakers concurred that "the criteria of OCA are endogenous" but worried that "the whole institutional setting is not included in the OCA criteria." 84 Although both Wim Duisenberg and Jean-Claude Trichet viewed the euro as a "strong catalyst for structural reforms in all non-financial domains in Europe," the ECB was not ready to rely on the invisible hand of market competition to achieve the criteria. ${ }^{85}$ Instead, it pledged to "cajole governments into implementing necessary structural reforms." 86 This, then, was the ECB's theory of change: in order for the euro area to achieve OCA status before the costs - in terms of low growth and high unemployment-grew too high, the ECB would have to take it on itself to plan for laissez-faire in the labor market.

\section{Market-enhancing integration: the ECB and structural labor market re- forms}

We divide the first two decades of EMU into four periods, each marked by a distinct combination of macroeconomic diagnoses, goals of the prescribed structural reform therapy, and theoretical resources mobilized by the ECB (see Table 3). Contrasting the dominant view of the ECB's role in this area, the first two sections below establish that the ECB's structural reform advocacy was at its most intense before the euro crisis.

greatest economic benefit if four criteria are met: labor mobility; price and wage flexibility; fiscal risksharing; synchronized business cycles. See Kenen, 1969; Mundell, 1961. For a critical discussion, see Schelkle, 2017.

${ }^{82}$ Commission, 1990; Jabko, 2006.

${ }^{83}$ Frankel and Rose, 1998.

${ }^{84}$ Interview 4, Appendix Appendix C.

${ }^{85}$ Speeches 10 and 11, Appendix Appendix B.

${ }^{86}$ Speech 6, Appendix Appendix B. 
Table 3: Four periods of structural reform advocacy by the ECB

\begin{tabular}{|c|c|c|c|c|}
\hline & 1999-2004 & 2005-2009 & 2010-2014 & 2015-2019 \\
\hline $\begin{array}{l}\text { Diagnosed } \\
\text { problem }\end{array}$ & $\begin{array}{l}\text { Unemployment } \\
\text { and low growth }\end{array}$ & $\begin{array}{l}\text { Diverging unit } \\
\text { labor costs / } \\
\text { competitiveness }\end{array}$ & $\begin{array}{l}\text { Diverged unit } \\
\text { labor costs / } \\
\text { competitiveness }\end{array}$ & $\begin{array}{l}\text { Deflationary } \\
\text { pressures }\end{array}$ \\
\hline $\begin{array}{l}\text { ECB } \\
\text { interests }\end{array}$ & $\begin{array}{l}\text { Organizational: } \\
\text { output legitimacy }\end{array}$ & $\begin{array}{l}\text { Organizational: } \\
\text { credibility }\end{array}$ & $\begin{array}{l}\text { Systemic: save } \\
\text { the currency (loss } \\
\text { of throughput } \\
\text { legitimacy } \\
\text { accepted) }\end{array}$ & $\begin{array}{l}\text { Organizational: } \\
\text { credibility and } \\
\text { throughput } \\
\text { legitimacy }\end{array}$ \\
\hline $\begin{array}{l}\text { Structural } \\
\text { reform goals }\end{array}$ & $\begin{array}{l}\text { Reduce } \\
\text { unemployment }\end{array}$ & $\begin{array}{l}\text { Macroeconomic } \\
\text { adjustment via } \\
\text { internal } \\
\text { devaluation }\end{array}$ & $\begin{array}{l}\text { Macroeconomic } \\
\text { adjustment via } \\
\text { internal } \\
\text { devaluation }\end{array}$ & - \\
\hline $\begin{array}{l}\text { Theoretical } \\
\text { basis of } \\
\text { epistemic } \\
\text { authority }\end{array}$ & $\begin{array}{l}\text { Brussels- } \\
\text { Frankfurt } \\
\text { consensus }\end{array}$ & $\begin{array}{l}\text { Optimum } \\
\text { currency area } \\
\text { theory }\end{array}$ & $\begin{array}{l}\text { "Expansionary } \\
\text { austerity" }\end{array}$ & $\begin{array}{l}\text { Secular } \\
\text { stagnation } \\
\text { (demand-side } \\
\text { deficiency) }\end{array}$ \\
\hline EU context & $\begin{array}{l}\text { Lisbon strategy; } \\
\text { Stability and } \\
\text { Growth Pact }\end{array}$ & $\begin{array}{l}\text { Lisbon mid-term } \\
\text { review }\end{array}$ & $\begin{array}{l}\text { Macroeconomic } \\
\text { adjustment } \\
\text { programs; } \\
\text { European } \\
\text { Semester }\end{array}$ & $\begin{array}{l}\text { Insufficient fiscal } \\
\text { expansion }\end{array}$ \\
\hline
\end{tabular}

\subsection{Structural reforms in a non-optimum currency area (1999-2004)}

The dominant macroeconomic problem at the beginning of phase three of EMU were high rates of unemployment. In terms of policy coordination, the Stability and Growth Pact was supposed to ensure fiscal discipline and protect the ECB's independence. ${ }^{87}$ The Amsterdam Treaty (1997) and the Lisbon Strategy (2000) signaled a commitment by governments to coordinate structural and social policies via the open method of coordination. ${ }^{88}$ For its part, the ECB intensified its communicative discourse on structural reforms throughout the presidency of Wim Duisenberg (1999-2003). While the dotted line in Figure 1 shows a consistently high share of speeches mentioning structural reforms, the relative frequency of the term (as a share of total words) doubled between 1999 and 2004 (solid line). Jean-Claude Trichet, Christian Noyer, and Wim Duisenberg were the

\footnotetext{
${ }^{87}$ See Artis and Winkler, 1998. The ECB was in favor of rules-based fiscal policy coordination and supported the Commission's proposals to reinforce the Pact's implementation in 2003. See Howarth, 2004; Trichet, 2004.

${ }^{88}$ Amable et al., 2009.
} 
Figure 1: "Structural reforms" and "structural policies" in ECB speeches, 1999-2019

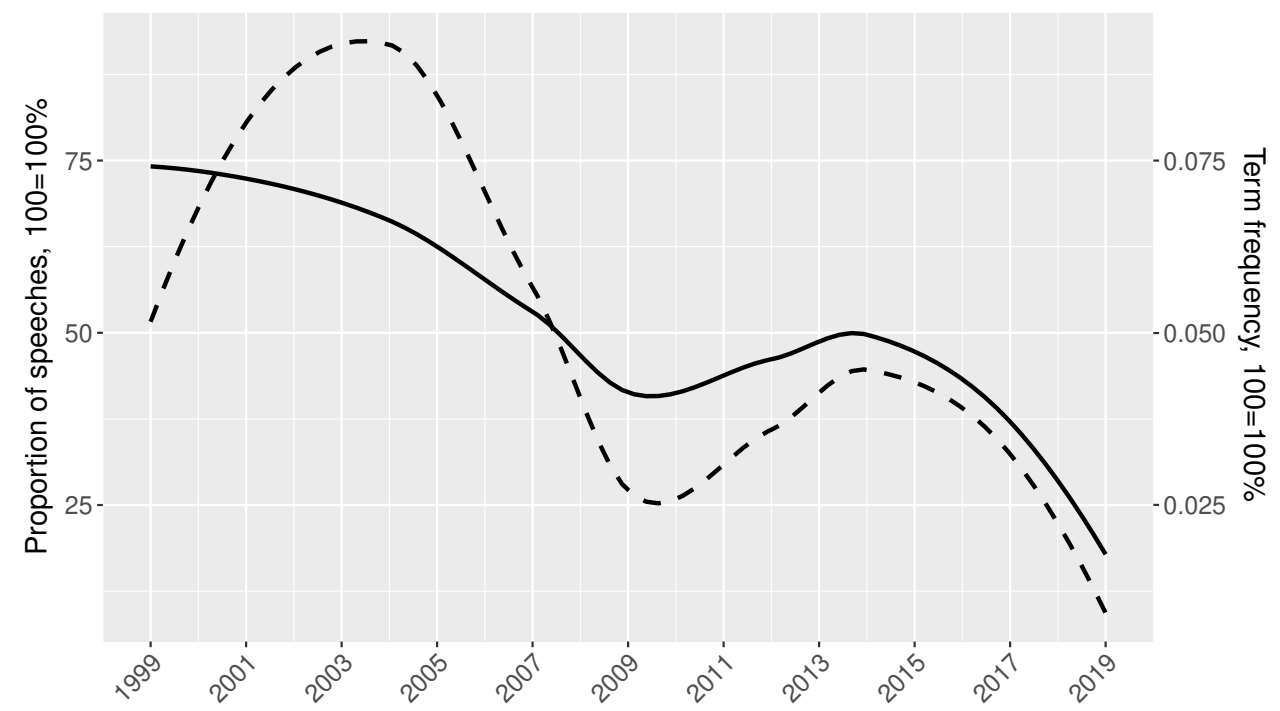

most active reform advocates on the ECB's Executive Board (Figure A.4, Appendix A). This supranational advocacy was reinforced at the national level by the Bundesbank, which was more vocal than the central banks of Italy and Spain (Figure A.5, Appendix A). ${ }^{89}$

The ECB's main concerns at the time were high unemployment and slow growth (Table 4 below and Figure A.6 in Appendix A). In keeping with the Brussels-Frankfurt consensus, the central bank argued consistently that monetary policy was inappropriate to address what it considered structural unemployment resulting from impeded market mechanisms and overly generous social security systems. ${ }^{90}$ Structural reforms were meant to increase allocative efficiency by removing institutional impediments to market coordination. To avoid shaming non-reforming governments directly, the ECB adopted the strategy of "naming and praising" successful structural reformers. ${ }^{91}$ Duisenberg stressed that member states "with more flexible labour markets, more moderate wage increases and less discouraging tax and social security policies, have managed to avoid the trend of ever-rising unemployment." 92

\footnotetext{
${ }^{89}$ Our dataset contains fewer than ten speeches per year for the NCBs of Italy and Spain for the first years of EMU.

${ }^{90}$ Speeches 1, 3 and 7, Appendix Appendix B.

${ }^{91}$ Interview 4, Appendix Appendix C. For examples, see speeches 4 and 17, Appendix Appendix B.

${ }^{92}$ Speech 4, Appendix Appendix B. The ECB also pointed to "best practices" beyond the euro area, praising the market-friendly nature of the US economy and the growth-enhancing character of its flexible labor markets; for example, speech 14, Appendix Appendix B.
} 
Table 4: Structural reform advocacy in ECB speeches, goals associated with structural reforms

\begin{tabular}{|c|c|c|c|c|c|}
\hline \multirow[b]{2}{*}{ Year } & \multicolumn{5}{|c|}{ Goals of Structural Reforms } \\
\hline & $\mathrm{RU}$ & GP & G1 & $\mathrm{G} 2$ & $\mathrm{OT}$ \\
\hline 1999 & 13 & 0 & 0 & 4 & 2 \\
\hline 2000 & 1 & 0 & 0 & 0 & 0 \\
\hline 2001 & 1 & 1 & 1 & 0 & 0 \\
\hline 2002 & 1 & 2 & 2 & 1 & 0 \\
\hline 2003 & 2 & 5 & 6 & 1 & 1 \\
\hline 2004 & 18 & 16 & 25 & 6 & 13 \\
\hline $\begin{array}{c}\sum 1^{\text {st }} \\
\text { Period: }\end{array}$ & 36 & 24 & 34 & 12 & 16 \\
\hline 2005 & 8 & 11 & 10 & 3 & 3 \\
\hline 2006 & 10 & 12 & 25 & 1 & 10 \\
\hline 2007 & 12 & 14 & 25 & 5 & 3 \\
\hline 2008 & 7 & 8 & 13 & 1 & 7 \\
\hline 2009 & 0 & 1 & 3 & 0 & 0 \\
\hline $\begin{array}{l}\sum 2^{\text {nd }} \\
\text { Period: }\end{array}$ & 37 & 46 & 76 & 10 & 24 \\
\hline 2010 & 2 & 3 & 0 & 0 & 2 \\
\hline 2011 & 1 & 5 & 4 & 0 & 2 \\
\hline 2012 & 5 & 7 & 7 & 0 & 0 \\
\hline 2013 & 7 & 11 & 20 & 0 & 6 \\
\hline 2014 & 12 & 21 & 27 & 1 & 10 \\
\hline $\begin{array}{c}\sum 3^{\text {rd }} \\
\text { Period: }\end{array}$ & 27 & 47 & 58 & 1 & 20 \\
\hline 2015 & 10 & 16 & 23 & 7 & 13 \\
\hline 2016 & 9 & 19 & 25 & 5 & 11 \\
\hline 2017 & 1 & 2 & 5 & 0 & 2 \\
\hline 2018 & 0 & 3 & 4 & 0 & 1 \\
\hline 2019 & 0 & 0 & 0 & 0 & 0 \\
\hline $\begin{array}{l}\sum 4^{\text {th }} \\
\text { Period: }\end{array}$ & 20 & 40 & 57 & 12 & 27 \\
\hline
\end{tabular}

Legend: $\quad \mathrm{RU}=$ Reduce unemployment, $\mathrm{GP}=$ Raise the growth potential, G1 = Increase competitiveness/productivity/adaptability, G2 = Maintain price stability/Improve transmission mechanisms, OT = Other 
Beyond the pursuit of organizational interests, the ECB sought to nudge governments into implementing the structural reforms necessary to ensure the viability of a non-optimum EMU. Fearing that the monetary union would remain vulnerable to asymmetric shocks no longer absorbable via exchange rates, the ECB explicitly deployed the endogeneity theory of OCA to justify its push for the liberalization of labor markets and the downgrading of social security systems. ${ }^{93}$ Our manual coding of the instruments advocated by Executive Board members reveals that, to the ECB, market-enhancing integration meant: to decentralize wage setting to the firm level (WS); to decrease unemployment benefits' generosity and availability (UB); and to decrease payroll taxes (LT). With slightly less emphasis, the ECB also advocated increasing spending on education, as well as on research and development (ER) (Table A1, Appendix A).

In sum, the ECB acted as a translator of structural reform pressures during the first years of EMU, providing justifications for-and "cajoling" governments into - the pursuit of reforms through its discursive advocacy. The ECB's organizational and systemic interests coincided throughout this period, as the central bank was preoccupied with structural reforms aimed at reducing unemployment and transforming EMU into an optimum currency area. However, the ECB soon found itself under political attack from the governments in Germany, France, and Italy for failing to spur growth and employment and - in the eyes of export-oriented Germany in particular - for Europe's diminished export competitiveness in light of the euro's strength vis-à-vis the US dollar. ${ }^{94}$ Duisenberg rejected governments' calls for interest rate cuts, arguing instead that they "could no longer hide behind the ECB to cover their failure to push through structural reforms." 95

\subsection{Structural reforms and public-sector wage restraint to stop divergence (2005-2009)}

The year 2005 marked a high point in the ECB's advocacy of structural labor market reforms and wage restraint. The mid-term review of the Lisbon Strategy in 2004 revealed that governments had only paid lip service to market-enhancing integration: "soft law" and the open method of coordination had failed. ${ }^{96}$ The ECB took notice of how uncoordinated wage policy had engendered mounting divergence in unit labor costs across the

\footnotetext{
${ }^{93}$ Speeches 11 and 23, Appendix Appendix B. Interviews 2, 3 and 4, Appendix Appendix C.

${ }^{94}$ Financial Times, 2003b.

${ }^{95}$ Financial Times, 2003a.

${ }^{96}$ Kok, 2004.
} 
Figure 2: "Unit labour costs" in ECB speeches, 1999-2019

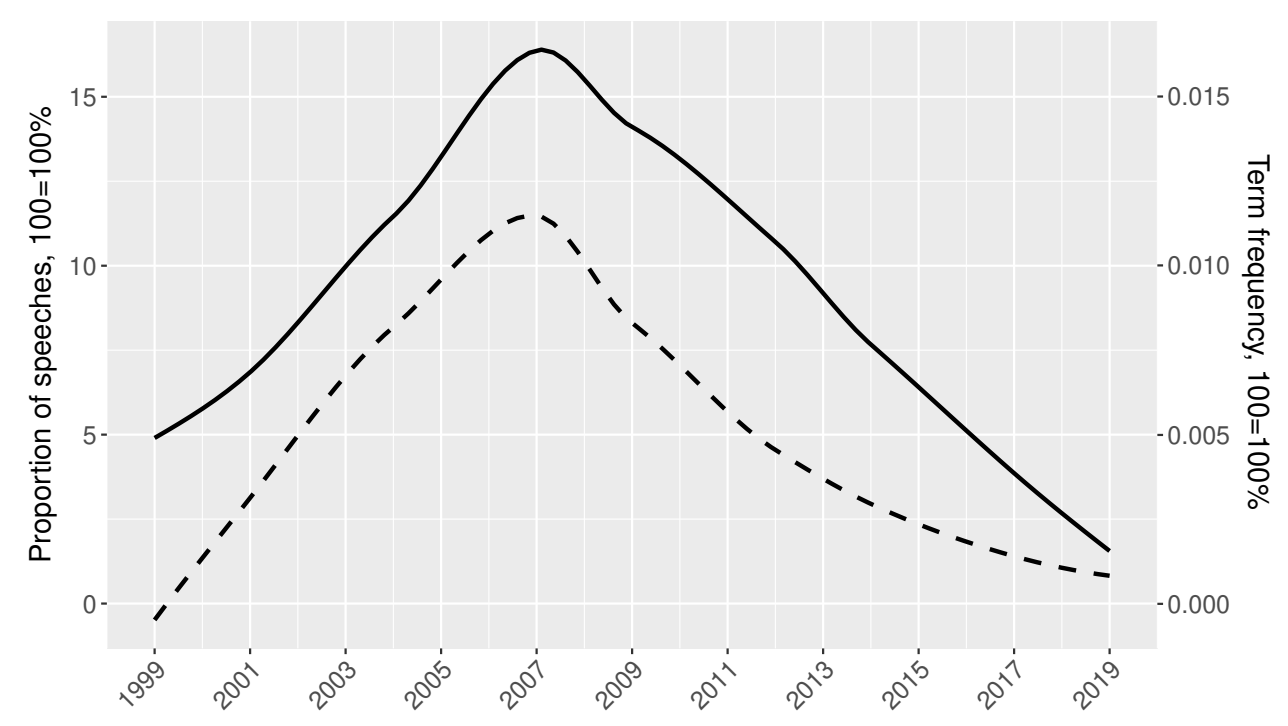

euro area. ${ }^{97}$ Intra-EMU inflation differentials risked undermining the singleness of the ECB's monetary transmission mechanism and thus jeopardized the very functioning of the monetary union. Consequently, the ECB's main preoccupation moved from aggregate inflation to the accumulation of economic imbalances in the euro area. ${ }^{98}$ The extent to which concerns for structural divergence took center stage in the ECB's communicative discourse is clear from the data: mentions of unit labor costs skyrocketed between 2004 and 2007 (Figure 2). Accordingly, the ECB reoriented its structural reforms advocacy towards the aim of improving member states' competitiveness via internal devaluation (Table 4).

The ECB pushed predominantly for the decentralization of wage-setting and the reduction of the tax burden on labor (Table A1, Appendix A). In addition, the ECB asked governments explicitly to eliminate wage indexation and enforce internal devaluations via public sector wage restraint. Jean-Claude Trichet was the most active carrier of this message (Figure A.4, Appendix A). In particular, Trichet called for an "[a]ppropriate handling of the unit labour costs in the civil service and public sector," which he maintained would avoid "painful national corrections through the competitive channel," suggesting that "the public sector should be a role model in terms of wage-setting and should not

\footnotetext{
${ }^{97}$ Gali, 1999. For studies of how this played out in EMU, see Copelovitch et al., 2016; Hancké, 2013; Johnston and Regan, 2016; Nölke, 2015.

${ }^{98}$ Interview 2, Appendix Appendix C.
} 
contribute to strong overall labor cost growth." 99 In fact, from 2005 - well before the onset of the global financial crisis - the ECB, in its coordinative discourse with European finance ministers in ECOFIN and Eurogroup meetings, warned of intra-EMU divergence in unit labor costs. Members of the Executive Board presented "competitiveness indicators" urged wage moderation via statutory wage restraint in the public sector. ${ }^{100}$

The year 2005 thus marked an underappreciated shift in the ECB's advocacy of structural reforms. The central bank continued to act as a translator of functional pressures but shifted its focus from unemployment to competitiveness and internal devaluation. Mounting structural divergence within EMU threatened both its organizational and systemic interests: while unit labor cost-driven inflation differentials hampered the ECB's one-size-fits-all monetary policy, thereby jeopardizing its output legitimacy and credibility, macroeconomic imbalances put the single currency as a whole at risk. In response, the ECB sought to convince governments to impose internal devaluation via the public sector and implement structural reforms aimed at regaining competitiveness. In doing so, it paved the ground for the interpretation of the euro area's sovereign debt crisis as a crisis of competitiveness divergence.

\subsection{Structural reforms to save the currency (2010-2014)}

The Greek debt crisis ushered in a period of "governing by panic" during which the ECB took the step from translating structural adjustment pressures to enforcing them. ${ }^{101}$ The defining macroeconomic concept of this period was that of so-called "expansionary austerity," formulated by Giavazzi and Pagano in the early 1990s and championed by Alesina and Ardagna during the crisis. ${ }^{102}$ Structural reforms were a functional corollary of expansionary austerity. Because the "expansionary effects of [contractionary] fiscal adjustments work via the labor market," proponents argued, "[s] upply-side policies ... are critical." 103 The consensus in favor of combining austerity and structural reforms to combat the crisis found its institutional expression in the European Semester and the

\footnotetext{
${ }^{99}$ Speeches 29 and 30, Appendix Appendix B. For references to wage indexation and public sector wage setting, see speeches between 6/29/2006 (25) and 10/12/2011 (33), Appendix Appendix B.

${ }^{100}$ Confirmed in interviews 2, 3 and 4, Appendix Appendix C. The ECB continued to use ECOFIN meetings to push for public-sector wage restraint after the financial crisis, see interview 5 , Appendix Appendix C.

${ }^{101}$ Woodruff, 2016.

${ }^{102}$ Alesina and Ardagna, 2010; Blyth, 2013; Dellepiane-Avellaneda, 2015; Giavazzi and Pagano, 1990; Helgadóttir, 2016.

${ }^{103}$ Alesina and Ardagna, 2010, p. 4; Alesina et al., 1998, p. 206; Theodoropoulou, 2018
} 
Macroeconomic Imbalance Procedure, overseen by the Commission. ${ }^{104}$

After a brief decline during the global financial crisis, structural labor market reforms quickly re-emerged as a prominent theme in the ECB's communicative discourse (Figure 1). The ECB continued to associate these reforms with the goal of enhancing countries' competitiveness (Table 4). The ECB's coordinative discourse gained in importance during the crisis in the context of frequent European Council meetings at which heads of state or government, amid growing uncertainty, turned to the ECB for guidance on economic policies. ${ }^{105}$ Although the European Commission has widely been seen as the progenitor of the competitiveness interpretation of the crisis, that interpretation took hold on ground that the ECB had been cultivating since 2005. ${ }^{106}$

As during the first years of EMU, the ECB's discursive advocacy for structural reforms was accompanied by restrictive monetary policy measures. In the context of the escalating Greek debt crisis, the central bank pondered toughening its collateral rules for sovereign bonds so as to "force the Greeks to get serious about fiscal discipline and economic reform." 107 A year later, in April and July 2011, the ECB hiked interest rates twice, despite a deteriorating economic outlook and against the view among economists that the situation in the euro area warranted continued monetary easing. ${ }^{108}$ During the press conference following the first hike, outgoing president Trichet stressed that it was "crucial that substantial and far-reaching structural reforms be urgently implemented in the euro area to strengthen its growth potential, competitiveness and flexibility." 109

The defining feature of the ECB's agency during this period, however, was its newly acquired capacity to impose formal and informal conditionality on member state governments. Formal conditionality was first applied in the IMF-EU lending programs to three non-EMU countries before 2010 (Hungary, Latvia, Romania), in which the ECB toed a more hawkish line than even the IMF. ${ }^{110}$ The experiment of those early lending programs

\footnotetext{
${ }^{104}$ Bauer and Becker, 2014; Hodson, 2018.

${ }^{105}$ Interview 2, Appendix Appendix C. See also Schmidt, 2020.

${ }^{106}$ For a critique of the competitiveness-divergence explanation of the euro crisis, see Jones, 2016.

${ }^{107}$ Tooze, 2018, p. 334.

${ }^{108}$ Mody, 2018, pp. 293-296.

${ }^{109}$ Trichet, 2011. Our interviewees denied that these decisions were intended to nudge governments into implementing structural reforms; see Interview 2, Appendix Appendix C. The ECB attributed the need for rate hikes to its organizational interests, pointing to fears that an uptick in HICP inflation would "translate into second-round effects in price and wage-setting behavior"; see Rostagno et al., 2019, pp. 191, 193.

${ }^{110}$ Ban, 2016, pp. 211-216; Fitoussi and Saraceno, 2013; Lütz and Kranke, 2014.
} 
Table 5: Structural reform advocacy in ECB speeches, type of advocated reform instruments (disembedding vs embedding flexibilization)

\begin{tabular}{ccc}
\hline & \multicolumn{2}{c}{ Instrument } \\
\cline { 2 - 3 } Year & Disembedding SRs & Embedded flexibilization SRs \\
\hline 1999 & 18 & 4 \\
2000 & 0 & 0 \\
2001 & 3 & 0 \\
2002 & 4 & 1 \\
2003 & 2 & 0 \\
2004 & 26 & 10 \\
\hline$\sum 1^{\text {st }}$ Period: & 53 & 15 \\
\hline 2005 & 6 & 4 \\
2006 & 33 & 10 \\
2007 & 35 & 9 \\
2008 & 26 & 6 \\
2009 & 0 & 1 \\
\hline \hline$\sum 2^{\text {nd }}$ Period: & 100 & 30 \\
\hline 2010 & 3 & 2 \\
2011 & 4 & 0 \\
2012 & 3 & 1 \\
2013 & 3 & 1 \\
2014 & 5 & 9 \\
\hline \hline$\sum 3^{\text {rd }}$ Period: & 18 & 13 \\
\hline 2015 & 6 & 11 \\
2016 & 3 & 5 \\
2017 & 1 & 2 \\
2018 & 0 & 0 \\
2019 & 0 & 18 \\
\hline \hline$\sum 4^{\text {th }}$ Period: & 9 & \\
\hline
\end{tabular}

then came to be institutionalized in the form of the "Troika," as a member of which the ECB, together with the Commission, closely monitored the implementation of fiscal consolidation and structural reforms in member states under macroeconomic adjustment programs. $^{111}$

The most striking case of ECB-imposed informal conditionality occurred in August 2011, when Trichet sent two secret letters to the prime ministers of Spain and Italy that implicitly made the continuation of the ECB's bond purchases (then under the Securities Markets Programme) conditional on the implementation of structural labor market reforms. The letter to Italy's Silvio Berlusconi, co-signed by Draghi, called for changes to the "collective wage bargaining system," "a thorough review of the rules regulating the hiring

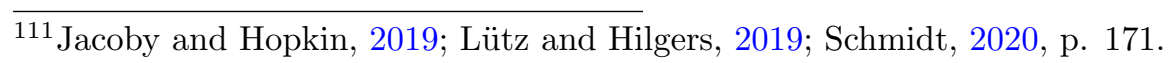


and dismissal of employees," and a new "unemployment insurance system." 112 Within less than a day, Italy's government announced that "the liberalization of all economic activities" would be enshrined in the country's constitution and that labor market reform would be fast-tracked for parliamentary approval as soon as "the following week." 113

The letter to Spain's Luis Zapatero went even further in both detail and scope. It called on the government to "abolish inflation-indexing clauses" and to "adopt exceptional measures to promote wage moderation in the private sector," including "a new exceptional work contract that is applied for a limited period of time, and where compensation for dismissal is very low." 114 Two days later, Spain's finance and acting deputy prime minister Elena Salgado gave a press conference pledging swift progress on labor market reform. Although the ECB carefully avoided any mention of bond purchases in either of its letters, the implicit message was clearly understood, and both were followed up by telephone calls by the central bank. ${ }^{115}$

The episode of the secret letters shows that in the presence of a systemic threat, organizational interests became a second-order concern for the ECB. The Italian letter was immediately leaked to the press, severely damaging the ECB's throughput legitimacy. Despite this predictable outcome, the ECB's leadership evidently considered it necessary to send the letters so as to bring about the type of reforms that, in its view, were needed to "save the currency." Both the ECB's willingness to enforce the strictures of the euro standard against elected governments and its readiness to do "whatever it takes to preserve the euro" - as Mario Draghi declared in the summer of 2012-suggest that the ECB's organizational interests were dominated by its systemic interest in the integrity of the euro area. ${ }^{116}$ Crucially, however, the reputational damage was not without consequences. As shown in Figure 3, questions about structural reforms put to the ECB president in the European Parliament's Monetary Dialogue increased steadily during this period, with a peak in 2014. Questions explicitly critical of the ECB's role spiked in 2015 - the beginning of the end of the ECB's structural reform advocacy.

\footnotetext{
${ }^{112}$ Corriere Della Sera, 2011.

${ }^{113}$ Rostagno et al., 2019, p. 195.

${ }^{114}$ Trichet and Ordoñez, 2011.

${ }^{115}$ Interview 2, Appendix Appendix C. See also Ban, 2016, pp. 202-204; Tooze, 2018, p. 398.

${ }^{116}$ Draghi, 2012.
} 
Figure 3: Questions about structural reforms posed by MEPs in the Monetary Dialogue, 2009-2019

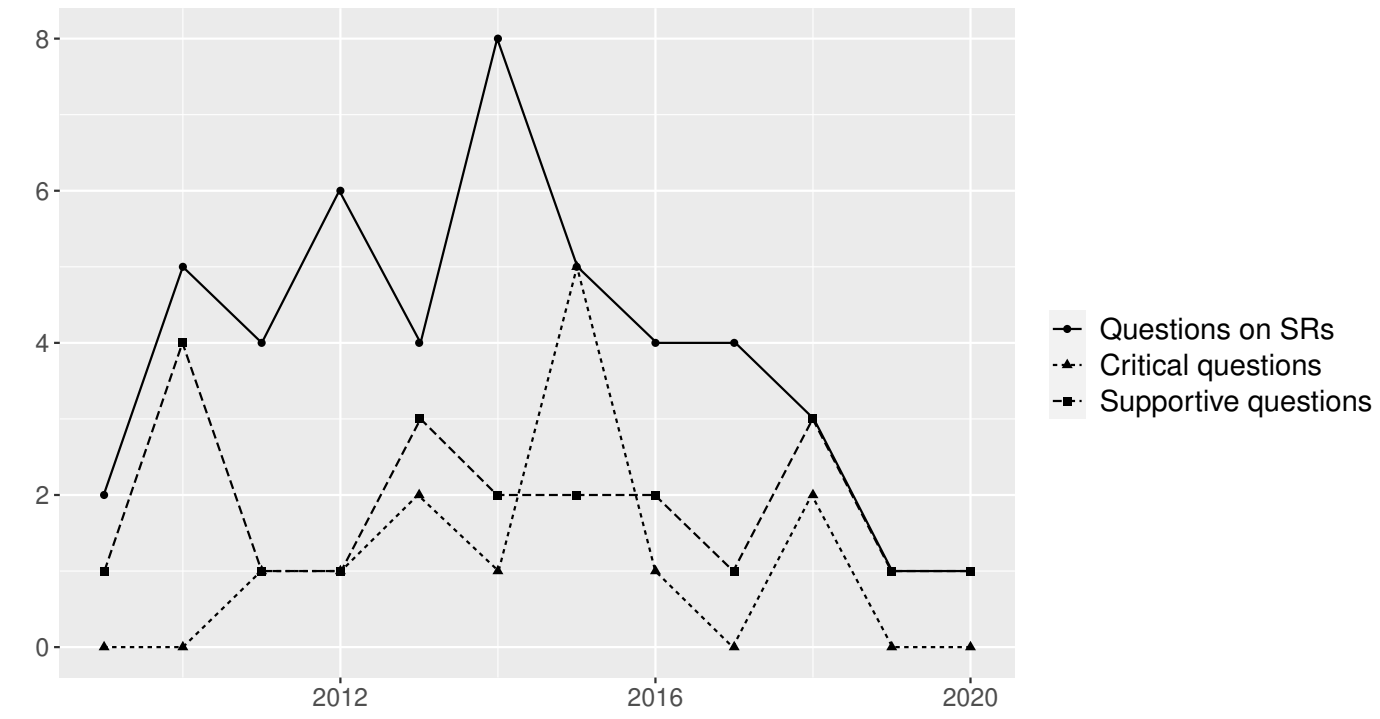

6.4. Deflation, QE, and the end of the ECB's structural reform advocacy (2015-2019)

With the threat of a breakup of the euro area largely off the table by 2015, the ECB's organizational interest in legitimacy can explain its gradual self-silencing on structural reforms (see Figure 1). In the throughput dimension of legitimacy, the ECB came under substantial pressure in the European Parliament. In July 2014, Draghi had been told by a Spanish MEP (Greens) that it was "high time" that the ECB "refrain from linking its monetary policy decisions to individual reforms in its public statements." ${ }^{117}$ In June 2015, when pressed over whether the ECB intended to keep up its structural reform advocacy, Draghi, referring to that earlier question, responded that "I have already been told I should not talk too much about structural reforms." 118 In September 2016, he stated that it was "certainly not in the ECB's mandate to suggest specific structural policies and agendas to different countries and different governments." 119

At least as pressing were the ECB's problems in the output dimension of legitimacy, which called into question the credibility of its monetary policy. By 2014, a "long slide in inflation" made it clear that, for the first time in its history, the ECB faced the threat of deflation. ${ }^{120}$ In light of new evidence strongly suggesting that the pursuit of structural reforms at the zero lower bound had been counterproductive- because of its tendency to

\footnotetext{
${ }^{117}$ European Parliament 2014.

${ }^{118}$ European Parliament 2015.

${ }^{119}$ European Parliament 2016.

${ }^{120}$ Rostagno et al., 2019, p. 205.
} 
raise real interest rates and depress aggregate demand - the European central bankers' folk theorem eventually came home to roost. ${ }^{121}$ Executive Board member Benoît Coeuré was among the first to concede that "in the short-term" structural reforms were "contractionary" and that there was thus "a need today (...) to focus less on achieving internal devaluation, and more on raising productivity." ${ }^{22}$ As Figure 1 shows, the ECB's discursive advocacy of structural reforms had dropped to near-zero by 2019 and shifted from an emphasis on disembedded to embedded flexibilization for the first time during this period, while the balance of goals it advocated remained broadly unchanged (Table 4).

Whereas the Federal Reserve, the Bank of Japan, and the Bank of England had been aggressively purchasing assets for several years, the ECB began to prepare its own quantitative easing (QE) program only in December 2014, when inflation had already turned negative. Against internal resistance, and in spite of expected challenges before the German Constitutional Court and the ECJ, the ECB's Asset Purchase Programme was eventually announced in January and launched in March 2015. ${ }^{123}$ Given the central bank's decision to deploy the last-resort measure of QE in order to fight deflation, it would have been plausible to assume that it also stopped calling for supply-increasing and demand-depressing structural reforms in its communicative discourse. However, although the ECB moved in this direction eventually, it continued to advocate for structural reforms even after the launch of QE. Our coding results confirm this continuity between the two years before and the two years after the start of the program, highlighting a persistent advocacy for reforms to raise the growth potential (GP) and to increase competitiveness (G1) (Table 4). ${ }^{124}$ This was accompanied by an increased emphasis on structural reforms as a way to foster investment ("Other", Table 4), mirroring the broader European embrace of a "social investment" discourse. ${ }^{125}$

In May 2015, at the ECB's flagship conference in Sintra, Portugal, Mario Draghi set the stage for the central bank's last discursive push to disembed national labor markets. Although he explicitly acknowledged that, with monetary policy at the zero lower bound,

\footnotetext{
${ }^{121}$ Eggertsson et al., 2014.

${ }^{122}$ Speech 37, Appendix Appendix B.

${ }^{123}$ De Boer and van't Klooster, 2020.

${ }^{124}$ Haas et al., 2020, p. 337 document a similar drop in the Commission's recommendations under the European Semester. See also Vesan et al., 2021. Diessner and Lisi, 2020 find that the ECB also reduced its communication on fiscal policy.

${ }^{125}$ Crespy and Vanheuverzwijn, 2019; Hemerijck, 2017.
} 
structural reforms had contractionary effects in the short term, Draghi rejected "the conclusion that this means all structural reforms should be postponed." ${ }^{126}$ He also reiterated his preference - voiced already in November 2014 - for the "governance of structural reforms to be exercised jointly at the euro area level." ${ }^{127}$ On this, Frankfurt was heard in Brussels. Building on earlier ad-hoc groups, the Commission, in July 2015, established the "Structural Reform Support Service," which, in January 2020, became part of the Commission's newly established Directorate-General for Structural Reform Support DG Reform. The ECB's renewed emphasis on structural reforms was also supported by the newly established "Expert group studying the causes of low inflation," which found that "excessive disinflation over the period [2012-2016] was primarily down to cyclical factors." 128 In light of the ECB's subsequent change of mind, it is important to note that this insistence on cyclical factors needs be read as a rejection of the alternative explanation of structurally weakened labor power.

And yet, starting in 2015, the ECB's discourse began to shift away from an unqualified preference for disembedding labor market reforms. The ECB's chief economist suggested that it was no longer "enough to give one-dimensional prescriptions such as that all labour markets must become more flexible," and recognized that the need for more tailor-made national reforms was something that "we could do a better job of conveying." 129 The economic background to this shift in the ECB's thinking was that wage growth remained sluggish in the euro area even as GDP growth resumed. By 2016, Mario Draghi saw an "unquestionable" case for higher wages, arguing that if low wages were to become a structural feature of the labor market, it would become difficult for the ECB to hit its inflation target. ${ }^{130}$ He even called for higher nominal wage increases in Northern member states, while attributing the lack of wage-push inflation to the expansion of low-quality temporary work in which unions have little bargaining clout. ${ }^{131}$

The ECB also began, for the first time, to problematize the social and economic costs of structural reforms - that is, their distributional and deflationary effects. In October 2017, the central bank hosted a conference on "Structural reforms in the euro area" at

\footnotetext{
${ }^{126}$ Speech 40, Appendix Appendix B.

${ }^{127}$ Speech 40, Appendix Appendix B. See also speech 38, Appendix Appendix B.

${ }^{128} \mathrm{ECB}, 2021$.

${ }^{129}$ Speech 41, Appendix Appendix B.

${ }^{130}$ Draghi, 2016.

${ }^{131}$ Financial Times, 2017.
} 
which Draghi explained that, because of "powerful vested interests," falling wages were not followed by falling prices, reducing workers' real incomes. He further called for "reforms with positive distributional effects," such as "active labour market policies that allow people to reskill." ${ }^{132}$ The following year, the ECB dedicated its conference in Sintra to the topic of "Price and wage-setting in advanced economies." There, Draghi applauded recent "growth in negotiated wages" and public-sector wages, notably in Germany, France, and Spain. ${ }^{133}$ The shift in emphasis in the titles of these two events - from reforms to the study of wage setting - encapsulates the ECB's conversion. Over the course of 2017 and 2018, it all but stopped talking about structural reforms. By 2019, the concept had disappeared from its public speeches altogether.

\section{Conclusion}

Speaking in 2015 at the ECB's annual forum on central banking, one distinguished economist noted that European central bankers "have been quite unspecific in their [structural] reform advocacy," and that a systematic analysis of the ECB's role in this area was long overdue. ${ }^{134}$ Performing such an analysis reveals that, despite the reputational costs, the ECB has been a highly articulate proponent of specific structural reforms in national labor markets and social policy regimes. During the early years, the ECB merely translated the functional pressures of the monetary regime for national governments. Under Duisenberg, it advocated flexible employment relations and atomistic wage setting as solutions to the high unemployment rates that posed a threat to the ECB's credibility and legitimacy. When unit labor cost divergence, first recognized and prioritized by Trichet, threatened the very effectiveness of supranational monetary policy, the ECB began to promote structural reforms as means of macroeconomic adjustment, both in public speeches and behind the scenes with national policymakers. Executive Board members urged governments to seek downward wage adjustments, both via structural labor market reforms and by imposing wage restraint on the public sector. When the euro-area debt crisis hit, the ground for its interpretation as a crisis of competitiveness divergence had already been prepared by the ECB. When circumstances added formal and informal conditionality to the ECB's toolkit, it wielded those instruments to help enforce labor market liberalization,

\footnotetext{
${ }^{132}$ Speech 45, Appendix Appendix B. ${ }^{133}$ Speech 47, Appendix Appendix B.

${ }^{134}$ Pisani-Ferry, 2015, p. 189.
} 
internal devaluation, and public sector wage cuts. It was only when deflationary pressures and criticism in the European Parliament and elsewhere threatened its legitimacy that the ECB abandoned its advocacy of structural reforms.

This paper fills a major gap in the Polanyi-inspired literature on the social potential of European integration. Notwithstanding the importance of the legal and political integration logics embodied by the ECJ and the Commission, our analysis shows how and why the introduction of the euro elevated the economic logic of monetary integration, embodied by the European Central Bank. Despite lacking both a mandate and the legal means to directly override national regulations, the ECB has been a keen supranational advocate of market-enhancing integration in the field of labor market and social policy.

This analysis also sheds new light on the broader political economy of central banking. Polanyi and others have shown that national central banking evolved under the international gold standard to buffer the disruptive adjustment pressures on national economies. The supranational ECB provided such protection for the financial system, but not for labor. Instead, emulating the role the IMF in other parts of the world, the ECB translated - and subsequently helped to enforce - the perceived functional pressures of international monetary and financial integration. Whether the ECB is constitutionally wedded to the role of "prime mover in the move to a market society" remains to be seen. ${ }^{135}$ Its recent shift from structural reform advocacy to calls for wage increases has been echoed in the US, where the Federal Reserve has signaled that it will prioritize employment and wage growth over consumer and asset price stabilization. Central banks may yet again become "active agents of the countermovement."

${ }^{135}$ Caporaso and Tarrow, 2009, p. 597. 


\section{References}

Aklin, M., Kern, A., \& Negre, M. (2021). Does Central Bank Independence Increase Inequality? World Bank Policy Research Working Paper, No. 9522.

Alesina, A., \& Ardagna, S. (2010). Large changes in fiscal policy: taxes versus spending. Tax policy and the economy, 24(1), 35-68.

Alesina, A., Perotti, R., Tavares, J., Obstfeld, M., \& Eichengreen, B. (1998). The Political Economy of Fiscal Adjustments. Brookings Papers on Economic Activity, 1998(1), 197. Available at $10.2307 / 2534672$

Amable, B., Demmou, L., \& Ledezma, I. (2009). The Lisbon strategy and structural reforms in Europe. Transfer: European Review of Labour and Research, 15(1), 3352.

Andor, L. (2013). Developing the social dimension of a deep and genuine Economic and Monetary Union. Policy Brief: European Policy Centre.

Artis, M., \& Winkler, B. (1998). The stability pact: safeguarding the credibility of the European Central Bank. National Institute Economic Review, 163(1), 87-98.

Baccaro, L., \& Howell, C. (2017). Trajectories of neoliberal transformation: European industrial relations since the 1970s. Cambridge University Press.

Baccaro, L., \& Rei, D. (2007). Institutional Determinants of Unemployment in OECD Countries: Does the Deregulatory View Hold Water? International Organization, $61(3), 527-569$.

Baccini, L., Guidi, M., Poletti, A., \& Yildirim, A. (forthc.). Trade Liberalization and Labor Market Institutions. International Organization.

Baerg, N. (2020). Crafting Consensus: Why Central Bankers Change Their Speech and How Speech Changes the Economy. Oxford, Oxford University Press.

Ban, C. (2016). Ruling ideas: How global neoliberalism goes local. Oxford University Press.

Bauer, M. W., \& Becker, S. (2014). The unexpected winner of the crisis: The European Commission's strengthened role in economic governance. Journal of European Integration, 36(3), 213-229.

Bazot, G., Monnet, E., \& Morys, M. (2019). Taming the Global Financial Cycle: Central Banks and the Sterilization of Capital Flows in the First Era of Globalization (1891-1913). 
Bazot, G., Monnet, E., \& Morys, M. (2020). The flexibility of the classical gold standard (1870s-1914): Any lessons for the eurozone? In J. E. Castañeda, A. Roselli, \& G. E. Wood (Eds.), The economics of monetary unions (pp. 17-30). Routledge.

Billows, S., Kohl, S., \& Tarissan, F. (2021). Bureaucrats or Ideologues? EU Merger Control as Market-centred Integration. JCMS: Journal of Common Market Studies, Advance Online Publication. Available at https://doi.org/10.1111/jcms.13130

Blyth, M. (2013). Austerity: The history of a dangerous idea. Oxford University Press.

Bodea, C., \& Hicks, R. (2015). Price Stability and Central Bank Independence: Discipline, Credibility, and Democratic Institutions. International Organization, 69(01), 3561. Available at $10.1017 / \mathrm{S} 0020818314000277$

Bordo, M., \& James, H. (2019). The trade-offs between macroeconomics, political economy and international relations. Financial History Review, 26(3), 247-266.

Boyer, R. (1993). D’une série de "National Labour Standards" à un "European Monetary Standard"? Recherches Économiques de Louvain, 59(1/2), 119-153.

Braun, B., Krampf, A., \& Murau, S. (2020). Financial globalization as positive integration: monetary technocrats and the Eurodollar market in the 1970s. Review of International Political Economy, 1-26. Available at 10.1080/09692290.2020.1740291

Broz, J. L., Frieden, J., \& Weymouth, S. (2021). Populism in Place: The Economic Geography of the Globalization Backlash. International Organization, Advance Online Publication, 1-31. Available at 10.1017/S0020818320000314

Bulfone, F., \& Afonso, A. (2020). Business against markets: employer resistance to collective bargaining liberalization during the eurozone crisis, journal = Comparative Political Studies, 53(5), 809-846.

Bulfone, F., \& Tassinari, A. (2020). Under pressure. Economic constraints, electoral politics and labour market reforms in Southern Europe in the decade of the Great Recession. European journal of political research, Advance Online Publication.

Capie, F., Caper, R., Fischer, S., Goodhart, C., \& Schnadt, N. (1994). The future of central banking: the tercentenary symposium of the Bank of England. Cambridge University Press.

Caporaso, J. A., \& Tarrow, S. (2009). Polanyi in Brussels: Supranational institutions and the transnational embedding of markets. International Organization, 593-620. 
Carstensen, Martin B. and Schmidt, Vivien A., t. =. P. (2016). Journal of European Public Policy, 23(3), 318-337. Available at 10.1080/13501763.2015.1115534

Collignon, S. (2009). The failure of the macroeconomic dialogue on wages (and how to fix it). In R. Letelier \& A. José Menéndez (Eds.), The sinews of european peace: Reconstituting the democratic legitimacy of the socio-economic constitution of the european union (pp. 427-467). Oslo, Centre for European Studies, University of Oslo.

Commission, E. (1990). One market, one money. An evaluation of the potential benefits and costs of forming an economic and monetary union. European Economy, 44 , $1-347$.

Copelovitch, M., Frieden, J., \& Walter, S. (2016). The Political Economy of the Euro Crisis. Comparative Political Studies, 49(7), 811-840. Available at 10.1177/0010414016633227

Corriere Della Sera. (2011). Trichet e Draghi: un'azione pressante per ristabilire la fiducia degli investitori. Available at https://www.corriere.it/economia/11_settembre_29/ trichet_draghi_inglese_304a5f1e-ea59-11e0-ae06-4da866778017.shtml

Crespy, A., \& Menz, G. (2015). Commission entrepreneurship and the debasing of social Europe before and after the Eurocrisis. JCMS: Journal of Common Market Studies, 53(4), 753-768.

Crespy, A., \& Vanheuverzwijn, P. (2019). What "Brussels" means by structural reforms: empty signifier or constructive ambiguity? Comparative European Politics, 17(1), 92-111. Available at 10.1057/s41295-017-0111-0

De Grauwe, P. (2006). What have we learnt about monetary integration since the Maastricht Treaty? JCMS: Journal of Common Market Studies, 44(4), 711-730.

de Boer, N., \& van't Klooster, J. (2020). The ECB, the courts and the issue of democratic legitimacy after Weiss. Common Market Law Review, 57(6), 28.

Dellepiane-Avellaneda, S. (2015). The Political Power of Economic Ideas: The Case of 'Expansionary Fiscal Contractions'. The British Journal of Politics and International Relations, 17(3), 391-418. Available at 10.1111/1467-856X.12038

Diessner, S., \& Lisi, G. (2020). Masters of the 'masters of the universe'? Monetary, fiscal and financial dominance in the Eurozone. Socio-Economic Review, 18(2), 315-335. 
Dietsch, P. (2020). Independent Agencies, Distribution, and Legitimacy: The Case of Central Banks. American Political Science Review, 114(2), 591-595. Available at $10.1017 / \mathrm{S} 0003055419000790$

Dobbin, F., Simmons, B., \& Garrett, G. (2007). The Global Diffusion of Public Policies: Social Construction, Coercion, Competition, or Learning? Annual Review of Sociology, 33(1), 449-472. Available at 10.1146/annurev.soc.33.090106.142507

Draghi, M. (2012). Whatever it takes. Speech at the Global Investment Conference in London.

Draghi, M. (2016). Introductory statement to the press conference.

Dyson, K. (2013). Sworn to Grim Necessity? Imperfections of European Economic Governance, Normative Political Theory, and Supreme Emergency. Journal of European Integration, 35(3), 207-222. Available at 10.1080/07036337.2013.774777

ECB. (1999). Box 4: The European Employment Pact. Monthly Bulletin, (June), 30-31.

ECB. (2017). What are structural reforms? Available at https://www.ecb.europa.eu/ explainers/tell-me/html/what-are-structural_reforms.en.html

ECB. (2021). Expert group studying the causes of low inflation (LIFT). Available at https: / / www. ecb.europa.eu/pub/economic-research / research-networks / html/ researcher_lift.en.html

Economist, T. (2019). The era of a "protective Europe" is dawning. The Economist. Available at https://www . economist.com/europe/2019/04/13/the-era- of- aprotective-europe-is-dawning

Eggertsson, G., Ferrero, A., \& Raffo, A. (2014). Can structural reforms help Europe? Journal of Monetary Economics, 61, 2-22.

Eichengreen, B., \& Temin, P. (2000). The Gold Standard and the Great Depression. Contemporary European History, 9(2), 183-207.

Eichengreen, B., \& Temin, P. (2010). Fetters of gold and paper. Oxford Review of Economic Policy, 26(3), 370-384.

EIRR. (1999). Implications of EMU for European Industrial Relations. European Industrial Relations Review, (301), 21-23.

Enderlein, H. (2006). Adjusting to EMU The Impact of Supranational Monetary Policy on Domestic Fiscal and Wage-Setting Institutions. European Union Politics, 7(1), 113-140. 
European Council. (1999). Annex I - Resolution of the European Council on the European Employment Pact.

Ferrara, F. M. (2020). The battle of ideas on the euro crisis: evidence from ECB intermeeting speeches. Journal of European Public Policy, 27(10), 1463-1486. Available at $10.1080 / 13501763.2019 .1670231$

Financial Times. (2003a). ECB rejects calls for more rate cuts.

Financial Times. (2003b). Ending the Blame Game.

Financial Times. (2017). Why the ECB wants unions to increase wage demands.

Fitoussi, J.-P., \& Saraceno, F. (2013). European economic governance: the Berlin-Washington Consensus. Cambridge Journal of Economics, 37(3), 479-496. Available at 10. 1093/cje/bet003

Fontan, C. (2018). Frankfurt's double standard: the politics of the European Central Bank during the Eurozone crisis. Cambridge Review of International Affairs, 31 (2), 162182. Available at $10.1080 / 09557571.2018 .1495692$

Frankel, J. A., \& Rose, A. K. (1998). The endogeneity of the optimum currency area criteria. The Economic Journal, 108(449), 1009-1025.

Gali, K. H. (1999). Wage growth and the inflation process: A multivariate cointegration analysis. Journal of Money, Credit and Banking, 417-431.

Garrett, G., Kelemen, R. D., \& Schulz, H. (1998). The European Court of Justice, National Governments, and Legal Integration in the European Union. International Organization, 52(1), 149-176.

Giavazzi, F., \& Pagano, M. (1990). Can Severe Fiscal Contractions Be Expansionary? Tales of Two Small European Countries. In Nber macroeconomics annual 1990, volume 5 (pp. 75-122). MIT Press.

Goetschy, J. (1999). The European employment strategy: Genesis and development. European Journal of Industrial Relations, 5(2), 117-137.

Goodman, J. B. (1992). Monetary sovereignty: The politics of central banking in Western Europe. Ithaca, NY, Cornell University Press.

Haas, J. S., D'Erman, V. J., Schulz, D. F., \& Verdun, A. (2020). Economic and fiscal policy coordination after the crisis: is the European Semester promoting more or less state intervention? Journal of European Integration, 42(3), 327-344. Available at 10.1080/07036337.2020.1730356 
Hall, P. A., \& Franzese, R. J. (1998). Mixed Signals: Central Bank Independence, Coordinated Wage Bargaining, and European Monetary Union. International Organization, 52(3), 505-535.

Hancké, B. (2013). Unions, central banks, and EMU: Labour market institutions and monetary integration in Europe. Oxford, Oxford University Press.

Heldt, E. C., \& Mueller, T. (2020). The (self-)empowerment of the European Central Bank during the sovereign debt crisis. Journal of European Integration, 1-16. Available at $10.1080 / 07036337.2020 .1729145$

Helgadóttir, O. (2016). The Bocconi boys go to Brussels: Italian economic ideas, professional networks and European austerity. Journal of European Public Policy, 23(3), 392-409.

Hemerijck, A. (2017). The uses of social investment. Oxford, Oxford University Press.

Henning, C. R. (2016). The ECB as a Strategic Actor: Central Banking in a Politically Fragmented Monetary Union. In J. A. Caporaso \& M. Rhodes (Eds.), The political and economic dynamics of the eurozone crisis. Oxford, Oxford University Press. Available at 10.1093/acprof:oso/9780198755739.003.0008

Hodson, D. (2018). The Macroeconomic Imbalance Procedure as European integration: a legalization perspective. Journal of European Public Policy, 25(11), 1610-1628.

Holmes, C. (2014). 'Whatever it takes': Polanyian perspectives on the eurozone crisis and the gold standard. Economy and Society, 43(4), 582-602. Available at 10.1080/ 03085147.2014 .959841

Höpner, M., \& Schäfer, A. (2010). A new phase of European integration: Organised capitalisms in post-Ricardian Europe. West European Politics, 33(2), 344-368.

Höpner, M., \& Schäfer, A. (2012). Embeddedness and regional integration: Waiting for Polanyi in a Hayekian setting. International Organization, 429-455.

Höpner, M., \& Spielau, A. (2018). Better Than the Euro? The European Monetary System (1979-1998). New Political Economy, 23(2), 160-173.

Howarth, D. (2004). The ECB and the Stability Pact: policeman and judge? Journal of European Public Policy, 11(5), 832-853.

Ikenberry, G. J. (1992). A world economy restored: expert consensus and the AngloAmerican postwar settlement. International organization, 46(1), 289-321. 
Issing, O. (2006). Europe's hard fix: the Euro area. International Economics and Economic Policy, 3(3), 181-196.

Jabko, N. (2006). Playing the Market: A Political Strategy for Uniting Europe, 1985-2005. Ithaca, Cornell University Press.

Jacobi, O. (1996). European Monetary Union - a quantum leap. Transfer: European Review of Labour and Research, 2(2), 233-244.

Jacobi, O. (1998). Contours of a European collective bargaining system under EMU. Transfer: European Review of Labour and Research, 4(2), 299-309.

Jacoby, W., \& Hopkin, J. (2019). From lever to club? Conditionality in the European Union during the financial crisis. Journal of European Public Policy, 27(8), 11571177. Available at 10.1080/13501763.2019.1703791

Johnston, A., \& Regan, A. (2016). European monetary integration and the incompatibility of national varieties of capitalism. JCMS: Journal of Common Market Studies, 54(2), 318-336.

Jones, E. (2013). The collapse of the Brussels-Frankfurt consensus and the future of the Euro. In V. A. Schmidt \& M. Thatcher (Eds.), Resilient liberalism in Europe's political economy (pp. 145-70). Cambridge, Cambridge University Press.

Jones, E. (2016). Competitiveness and the European financial crisis. The political and economic dynamics of the Eurozone crisis, 79-99.

Keefer, P., \& Stasavage, D. (n.d.). The limits of delegation: Veto players, central bank independence, and the credibility of monetary policy. American Political Science Review.

Kenen, P. B. (1969). The theory of optimum currency areas: An Eclectic View. In R. A. Mundell \& A. K. Swoboda (Eds.), Monetary problems of the international economy. Chicago, Chicago University Press.

Kentikelenis, A. E. (2018). The social aftermath of economic disaster: Karl Polanyi, countermovements in action, and the Greek crisis. Socio-Economic Review, 16(1), 39 59.

Kentikelenis, A. E., \& Babb, S. (2019). The Making of Neoliberal Globalization: Norm Substitution and the Politics of Clandestine Institutional Change. American Journal of Sociology, 124(6), 1720-1762. 
Keohane, R. O. (1978). Review: Economics, Inflation, and the Role of the State: Political Implications of the McCracken Report. World Politics, 31(1), 108-128.

Klein, S. (2020). European Law and the Dilemmas of Democratic Capitalism. Global Perspectives, 1(1), 133-178.

Knafo, S. (2013). The Making of Modern Finance: Liberal Governance and the Gold Standard. Abingdon, Routledge.

Kok, W. (2004). Facing the challenge: The Lisbon strategy for growth and employment. Luxembourg, Office for Official Publications of the European Communities.

Leibfried, S., \& Pierson, P. (1992). Prospects for social Europe. Politics E Society, 20(3), $333-366$.

Lipson, C. (1985). Standing guard: Protecting foreign capital in the nineteenth and twentieth centuries (Vol. 11). Berkeley, CA, University of California Press.

Lohmann, S. (2003). Why Do Institutions Matter? An Audience-Cost Theory of Institutional Commitment. Governance, 16(1), 95-110. Available at 10.1111/14680491.t01-1-00209

Lütz, S., \& Hilgers, S. (2019). When overlapping organisations play two-level games: IMFEU interaction in credit lending to Latvia and Greece. New Political Economy, $24(3), 299-312$.

Lütz, S., \& Kranke, M. (2014). The European rescue of the Washington Consensus? EU and IMF lending to Central and Eastern European countries. Review of International Political Economy, 21(2), 310-338.

Marginson, P., \& Sisson, K. (1998). European collective bargaining: a virtual prospect? JCMS: Journal of Common Market Studies, 36(4), 505-528.

McNamara, K. R., Matthijs, M., \& Blyth, M. (2015). The Forgotten Problem of Embeddedness. In M. Matthijs \& M. Blyth (Eds.), The future of the Euro (pp. 21-43). Oxford, Oxford University Press.

Mody, A. (2018). EuroTragedy: a drama in nine acts. Oxford University Press.

Morel, N., Palier, B., \& Palme, J. (2012). Towards a social investment welfare state? Ideas, policies and challenges. Bristol, Policy Press.

Morrison, J. A. (2016). Shocking intellectual austerity: the role of ideas in the demise of the gold standard in Britain. International Organization, 175-207. 
Moschella, M., Pinto, L., \& Martocchia Diodati, N. (2020). Let's speak more? How the ECB responds to public contestation. Journal of European Public Policy, 27(3), 400-418. Available at 10.1080/13501763.2020.1712457

Mudge, S. L., \& Vauchez, A. (2016). Fielding supranationalism: the European Central Bank as a field effect. The Sociological Review Monographs, 64(2), 146-169. Available at 10.1002/2059-7932.12006

Mundell, R. A. (1961). A Theory of Optimum Currency Areas. The American Economic Review, 51(4), 657-665.

Mundell, R. A. (1963). Capital mobility and stabilization policy under fixed and flexible exchange rates. The Canadian Journal of Economics and Political Science, 29(4), $475-485$.

Nelson, S. C., \& Katzenstein, P. J. (2014). Uncertainty, Risk, and the Financial Crisis of 2008. International Organization, 68(2), 361-392. Available at 10.1017/ S0020818313000416

Nölke, A. (2015). Economic causes of the Eurozone crisis: the analytical contribution of Comparative Capitalism. Socio-Economic Review, 14(1), 141-161. Available at $10.1093 / \mathrm{ser} / \mathrm{mwv} 031$

Pisani-Ferry, J. (2015). Central bank advocacy of structural reform: why and how? Inflation and unemployment in Europe, 185.

Polanyi, K. (2001). The Great Transformation. The Political and Economic Origins of Our Time. Boston, MA, Beacon Press.

Rathgeb, P., \& Tassinari, A. (2020). How the Eurozone disempowers trade unions: the political economy of competitive internal devaluation. Socio-Economic Review, Advance Online Publication. Available at 10.1093/ser/mwaa021

Reinsberg, B., Stubbs, T., Kentikelenis, A., \& King, L. (2019). The political economy of labor market deregulation during IMF interventions. International Interactions, 45(3), 532-559. Available at 10.1080/03050629.2019.1582531

Rieth, M., \& Wittich, J. (2020). The impact of ECB policy on structural reforms. European Economic Review, 122, 103361. Available at https://doi.org/10.1016/j.euroecorev. 2019.103361

Roos, J. (2019). Why Not Default? The Political Economy of Sovereign Debt. Princeton, NJ, Princeton University Press. 
Rostagno, M., Altavilla, C., Carboni, G., Lemke, W., Motto, R., Saint Guilhem, A., \& Yiangou, J. (2019). A tale of two decades: The ECB's monetary policy at 20. ECB working paper.

Ruggie, J. G. (1982). International regimes, transactions, and change: embedded liberalism in the postwar economic order. International organization, 36(2), 379-415.

Ruggie, J. G. (1995). At home abroad, abroad at home: international liberalisation and domestic stability in the new world economy. Millennium, 24(3), 507-526.

Sacchi, S. (2015). Conditionality by other means: EU involvement in Italy's structural reforms in the sovereign debt crisis. Comparative European Politics, 13(1), 77-92.

Saurugger, S., \& Fontan, C. (2019). The judicialisation of EMU politics: Resistance to the EU's new economic governance mechanisms at the domestic level. European Journal of Political Research, 58(4), 1066-1087.

Scharpf, F. W. (1991). Crisis and choice in European social democracy. Ithaca, Cornell University Press.

Scharpf, F. W. (1997). Economic integration, democracy and the welfare state. Journal of European Public Policy, 4(1), 18-36. Available at 10.1080/135017697344217

Scharpf, F. W. (1999). Governing in Europe: Effective and democratic? Oxford, Oxford University Press.

Scharpf, F. W. (2010). The asymmetry of European integration, or why the EU cannot be a 'social market economy'. Socio-economic review, 8(2), 211-250.

Scharpf, F. W. (2011). Monetary union, fiscal crisis and the pre-emption of democracy. Zeitschrift für Staats-und Europawissenschaften, 163-198.

Scharpf, F. W. (2016). Forced structural convergence in the eurozone: Or a differentiated European monetary community (tech. rep.). MPIfG Discussion Paper.

Schelkle, W. (2017). The political economy of monetary solidarity: understanding the euro experiment. Oxford, Oxford University Press.

Schmidt, V. A. (2008). Discursive Institutionalism: The Explanatory Power of Ideas and Discourse. Annual Review of Political Science, 11(1), 303-326. Available at doi: 10.1146/annurev.polisci.11.060606.135342

Schmidt, V. A. (2016). Reinterpreting the rules 'by stealth'in times of crisis: a discursive institutionalist analysis of the European Central Bank and the European Commission. West European Politics, 39(5), 1032-1052. 
Schmidt, V. A. (2020). Europe's crisis of legitimacy: Governing by rules and ruling by numbers in the eurozone. Oxford, Oxford University Press.

Seccareccia, M., \& Correa, E. (2017). Supra-national money and the Euro crisis: Lessons from Karl Polanyi, In Forum for Social Economics, Taylor \& Francis.

Simmons, B. A. (1994). Who adjusts? Domestic sources of foreign economic policy during the interwar years (Vol. 175). Princeton, NJ, Princeton University Press.

Simoni, M., \& Vlandas, T. (2020). Labour market liberalization and the rise of dualism in Europe as the interplay between governments, trade unions and the economy. Social Policy $6 \mathcal{G}$ Administration, Advance Online Access.

Solow, R. M. (1998). What is Labour-Market Flexibility? What is it Good for? Proceedings of the British Academy, 97, 189-211.

Streeck, W. (1995). From market making to state building? Reflections on the political economy of European social policy. In P. Pierson \& S. Leibfried (Eds.), European social policy: Between fragmentation and integration (p. 416). Washington, DC, Brookings Institution Press.

Streeck, W. (2019). Progressive Regression: Metamorphoses of European Social Policy. New Left Review, (118), 117-139.

Thelen, K. (2014). Varieties of liberalization and the new politics of social solidarity. Cambridge, Cambridge University Press.

Theodoropoulou, S. (2016). National social and labour market policy reforms in the shadow of EU Bailout conditionality: The cases of Greece and Portugal, In The Sovereign Debt Crisis, the EU and Welfare State Reform. Springer.

Theodoropoulou, S. (2018). Labour market policies in the era of pervasive austerity: a European perspective. Bristol, Policy Press.

Tooze, A. (2018). Crashed: How a decade of financial crises changed the world. Penguin.

Trichet, J.-C. (2004). Lecture on the occasion of the receipt of the EFR-Business Week Award 2004. Available at https://www.ecb.europa.eu/press / key/date/2004/ html/sp040420.en.html

Trichet, J.-C. (2011). Introductory statement to the press conference (with Q\&A), 7 April. Available at https://www.ecb.europa.eu/press/pressconf/2011/html/is110407.en. html 
Trichet, J.-C., \& Ordoñez, M. F. (2011). Letter from Trichet and Fernandez Ordonez to Zapatero (declassified on 12/19/2014). Available at https://www.ecb.europa. $\mathrm{eu} / \mathrm{pub}$ / pdf / other / 2011-08-05- letter-from- trichet- and-fernandez- ordonez- tozapateroen.pdf

Triffin, R. (1946). National Central Banking and the International Economy. The Review of Economic Studies, 14(2), 53-75. Available at 10.2307/2296086

Van Gyes, G., \& Schulten, T. (2015). Wage bargaining under the new European Economic Governance: Alternative strategies for inclusive growth. ETUI.

Verdun, A. (1999). The role of the Delors Committee in the creation of EMU: an epistemic community? Journal of European Public Policy, 6(2), 308-328.

Vermeiren, M. (2017). One-size-fits-some! Capitalist diversity, sectoral interests and monetary policy in the euro area. Review of International Political Economy, 24(6), 929-957. Available at 10.1080/09692290.2017.1377628

Vesan, P., Corti, F., \& Sabato, S. (2021). The European Commission's entrepreneurship and the social dimension of the European Semester: from the European Pillar of Social Rights to the Covid-19 pandemic. Comparative European Politics, 1-19.

Walter, S. (2013). Financial crises and the politics of macroeconomic adjustments. Cambridge, Cambridge University Press.

Walter, S. (2021). The Backlash Against Globalization. Annual Review of Political Science, 24 (1). Available at 10.1146/annurev-polisci-041719-102405

Weingast, B. R. (1995). The economic role of political institutions: Market-preserving federalism and economic development. Journal of Law, Economics, 65 Organization, $11(1), 1-31$.

Woodruff, D. M. (2016). Governing by panic: The politics of the Eurozone crisis. Politics ES Society, 44(1), 81-116. 


\section{Appendix}

\section{A. Additional tables and figures}

Table A.6: Disaggregated reform instruments advocated by ECB, 1999-2019

\begin{tabular}{|c|c|c|c|c|c|c|c|c|c|c|c|c|}
\hline \multirow[b]{2}{*}{ Year } & \multicolumn{12}{|c|}{ Structural Reform Instruments and Settings } \\
\hline & LT & UB & EPL & $\mathrm{EC}$ & WT & RA & WS & EW & MW & ALMP & ER & IOT \\
\hline 1999 & 5 & 5 & 0 & 0 & 0 & 0 & 4 & 0 & 4 & 4 & 0 & 0 \\
\hline 2000 & 0 & 0 & 0 & 0 & 0 & 0 & 0 & 0 & 0 & 0 & 0 & 0 \\
\hline 2001 & 1 & 1 & 1 & 0 & 0 & 0 & 0 & 0 & 0 & 0 & 0 & 0 \\
\hline 2002 & 1 & 1 & 1 & 0 & 0 & 0 & 1 & 0 & 0 & 1 & 0 & 0 \\
\hline 2003 & 1 & 0 & 0 & 0 & 1 & 0 & 0 & 0 & 0 & 0 & 0 & 0 \\
\hline 2004 & 5 & 6 & 1 & 3 & 1 & 1 & 6 & 2 & 1 & 3 & 7 & 0 \\
\hline$\sum \sum 1^{\text {st }}$ & 13 & 13 & 3 & 3 & 2 & 1 & 11 & 2 & 5 & 8 & 7 & 0 \\
\hline \multicolumn{13}{|l|}{ Period: } \\
\hline 2005 & 1 & 2 & 0 & 0 & 0 & 1 & 0 & 2 & 0 & 0 & 4 & 0 \\
\hline 2006 & 6 & 6 & 4 & 4 & 2 & 1 & 6 & 4 & 0 & 0 & 6 & 4 \\
\hline 2007 & 5 & 6 & 6 & 4 & 0 & 1 & 10 & 2 & 1 & 2 & 6 & 1 \\
\hline 2008 & 6 & 5 & 3 & 5 & 0 & 1 & 6 & 0 & 0 & 0 & 6 & 0 \\
\hline 2009 & 0 & 0 & 0 & 0 & 0 & 0 & 0 & 0 & 0 & 0 & 1 & 0 \\
\hline$\sum \sum 2^{\text {nd }}$ & 18 & 19 & 13 & 13 & 2 & 4 & 22 & 8 & 1 & 2 & 23 & 5 \\
\hline \multicolumn{13}{|l|}{ Period: } \\
\hline 2010 & 1 & 1 & 0 & 0 & 0 & 0 & 1 & 0 & 0 & 0 & 2 & 0 \\
\hline 2011 & 1 & 1 & 1 & 0 & 0 & 0 & 1 & 0 & 0 & 0 & 0 & 0 \\
\hline 2012 & 0 & 0 & 0 & 0 & 0 & 0 & 2 & 0 & 1 & 0 & 1 & 0 \\
\hline 2013 & 0 & 1 & 0 & 0 & 0 & 0 & 2 & 0 & 0 & 1 & 0 & 0 \\
\hline 2014 & 0 & 2 & 1 & 0 & 0 & 0 & 2 & 0 & 0 & 4 & 3 & 2 \\
\hline$\overline{\sum \sum 3^{\text {rd }}}$ & 2 & $\overline{5}$ & 2 & 0 & 0 & 0 & 8 & 0 & 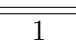 & 5 & 6 & 2 \\
\hline \multicolumn{13}{|l|}{ Period: } \\
\hline 2015 & 0 & 1 & 1 & 1 & 0 & 0 & 3 & 0 & 0 & 6 & 5 & 0 \\
\hline 2016 & 1 & 0 & 1 & 0 & 0 & 0 & 1 & 0 & 0 & 2 & 3 & 0 \\
\hline 2017 & 0 & 0 & 0 & 0 & 0 & 0 & 1 & 0 & 0 & 1 & 1 & 0 \\
\hline 2018 & 0 & 0 & 0 & 0 & 0 & 0 & 0 & 0 & 0 & 0 & 0 & 0 \\
\hline 2019 & 0 & 0 & 0 & 0 & 0 & 0 & 0 & 0 & 0 & 0 & 0 & 0 \\
\hline$\sum \sum 4^{\text {th }}$ & $\overline{1} 1$ & $\overline{1} 1$ & 2 & 1 & $\overline{0}$ & $\overline{0}$ & 5 & $\overline{0}$ & $\overline{0}$ & 9 & $\overline{99}$ & 0 \\
\hline Period: & & & & & & & & & & & & \\
\hline
\end{tabular}

Legend: $\mathrm{LT}=$ Decrease tax burden on labour, UB $=$ Decrease generosity/availability of unemployment benefits, EPL $=$ Decrease protection against job dismissals, $\mathrm{EC}=$ Make use of flexible employment contracts, WT = Increase working time, RA = Increase retirement age, WS = Need for lower wages/wage restraint, $\mathrm{EW}=$ Decrease generosity/availability of early withdrawal schemes, $\mathrm{MW}=$ Decrease minimum wage, ALMP $=$ Increase availability of ALMPs, ER $=$ Increase spending on Education, Research and Development, IOT $=$ Other Instruments (provision of child care and reduction of labour market dualities) 
Figure A.4: Top-5 structural reform advocates among ECB Executive Board members (share of speeches that mention "structural reform", 1 = 100\%)

1999-2004

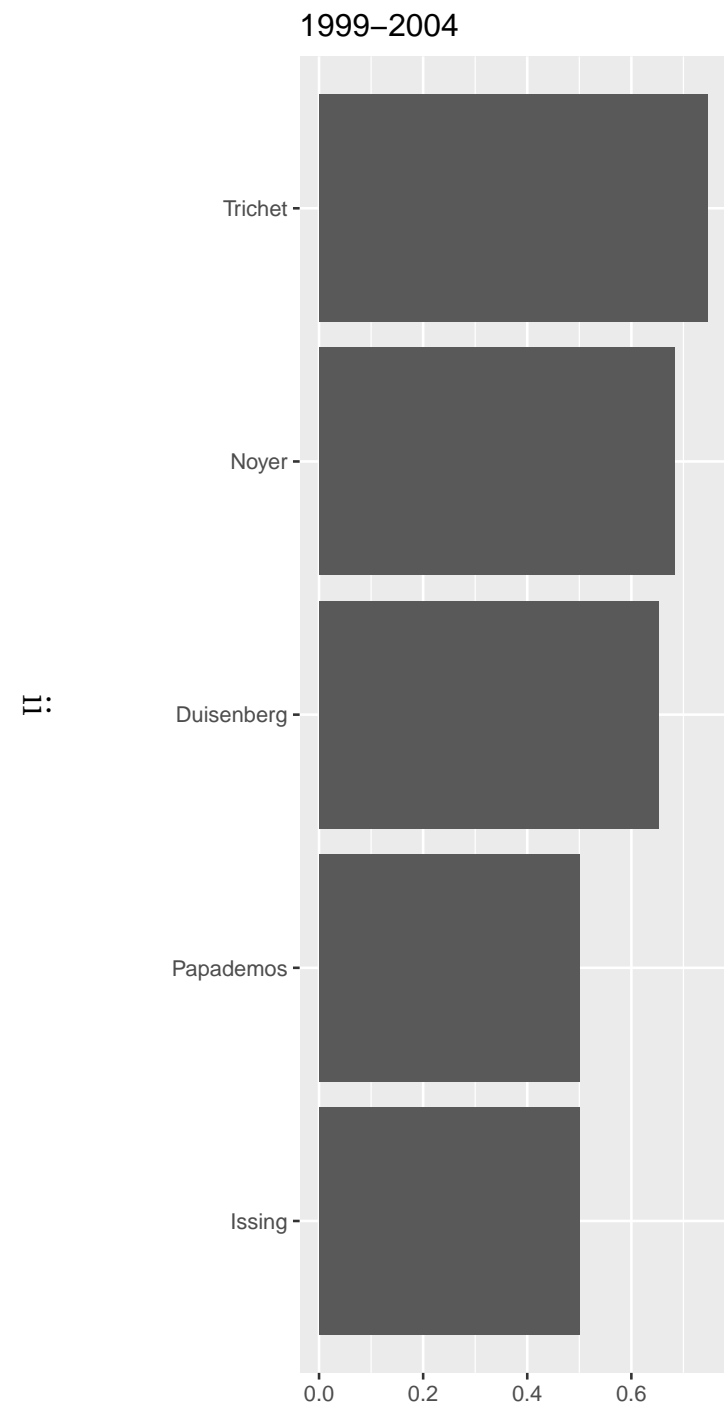

2005-2009

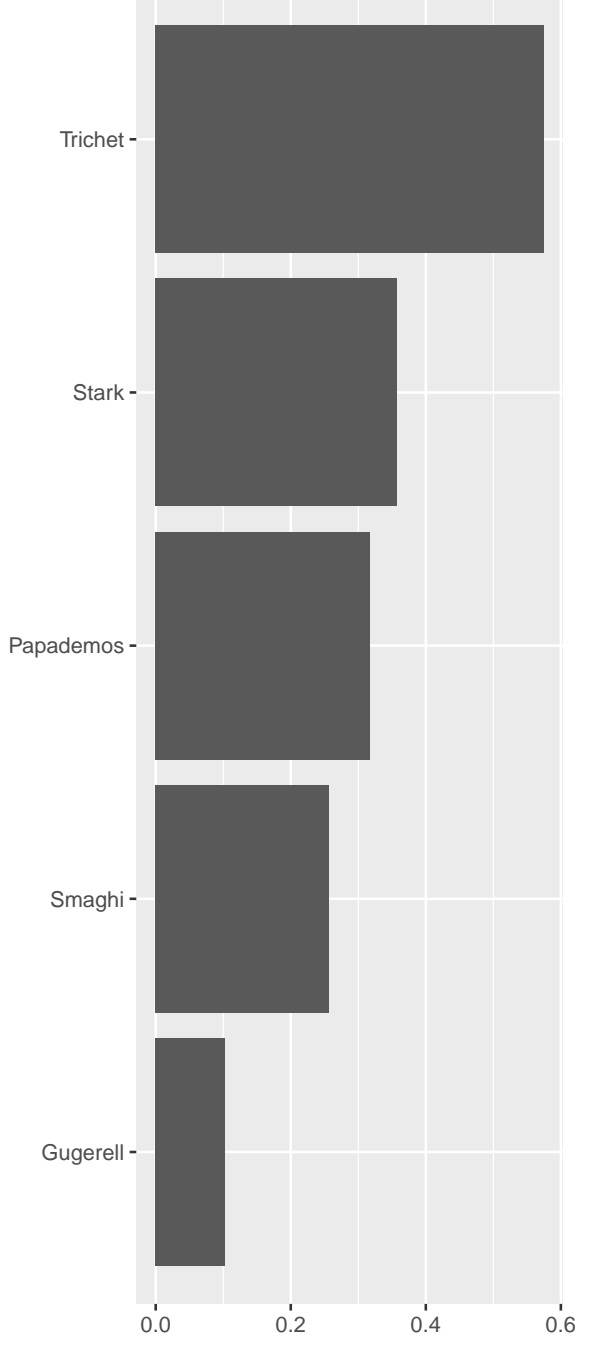

2010-2015
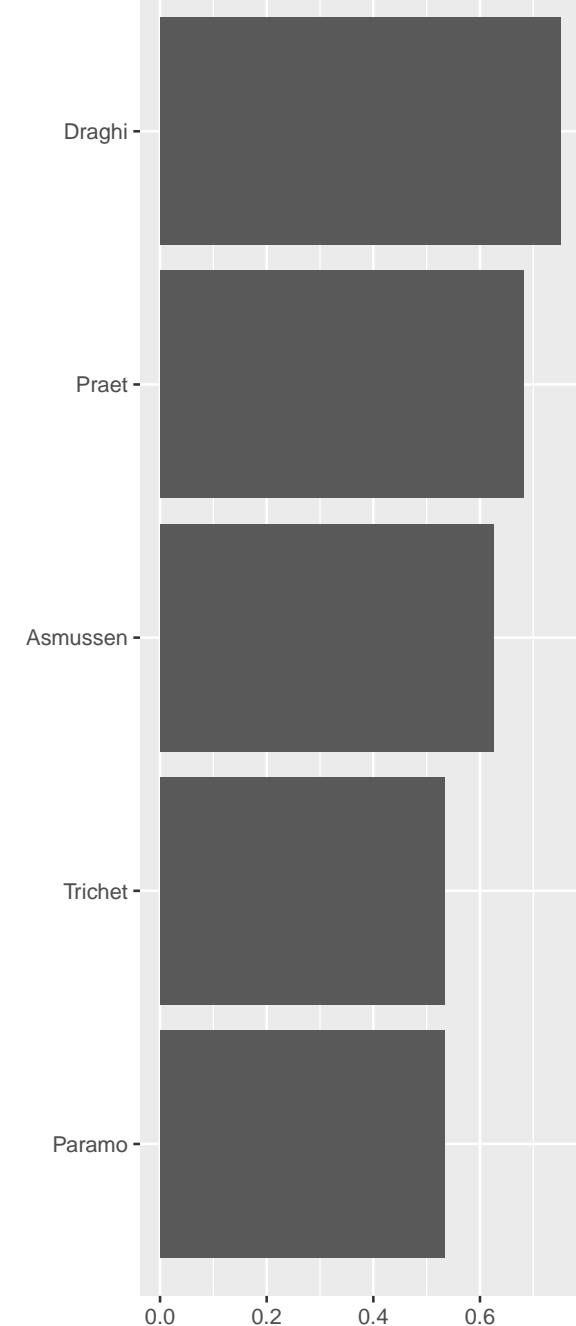

2016-2019

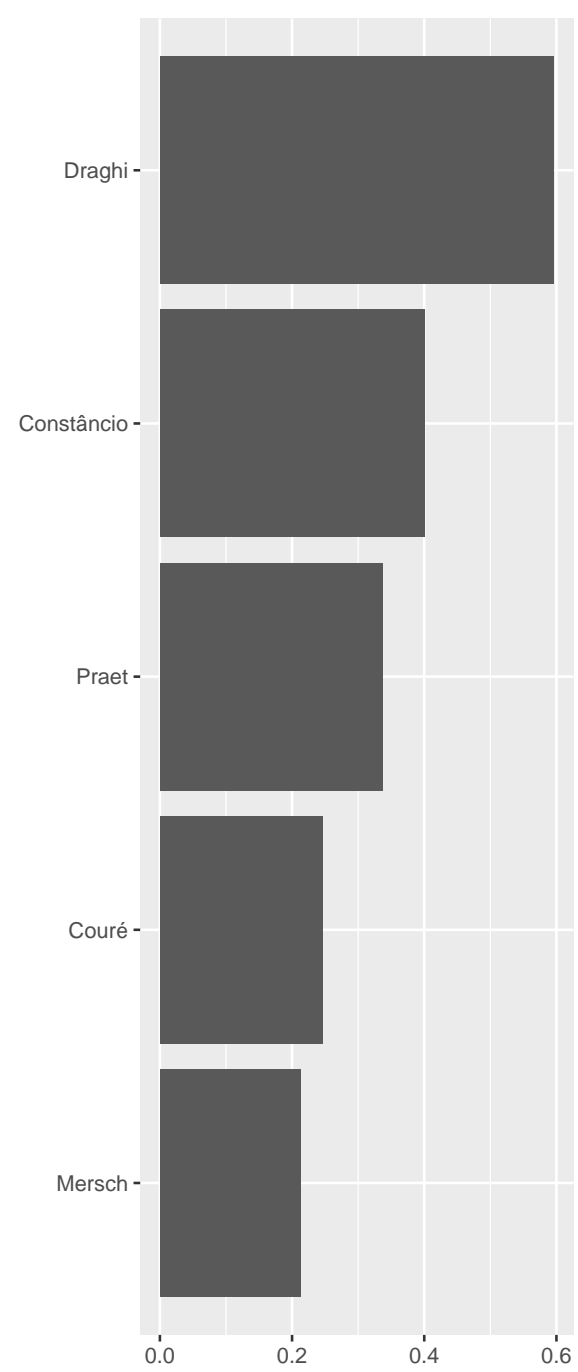

Share of speeches, $1=100 \%$ 
Figure A.5: "Structural reforms" and "structural policy" in the speeches of the major national central banks, 1999-2019
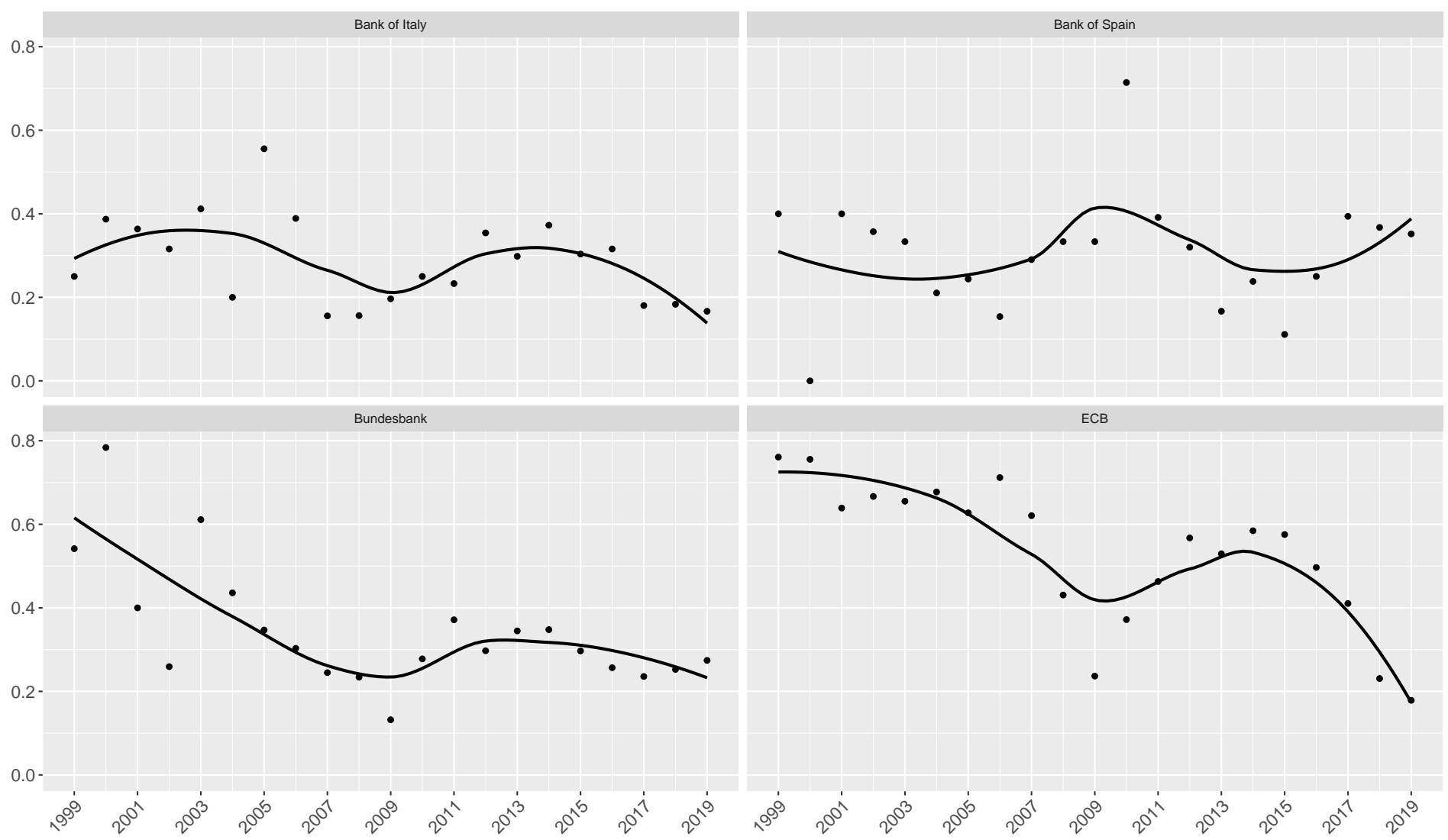
Figure A.6: Selected collocations of "structural reform/policy"

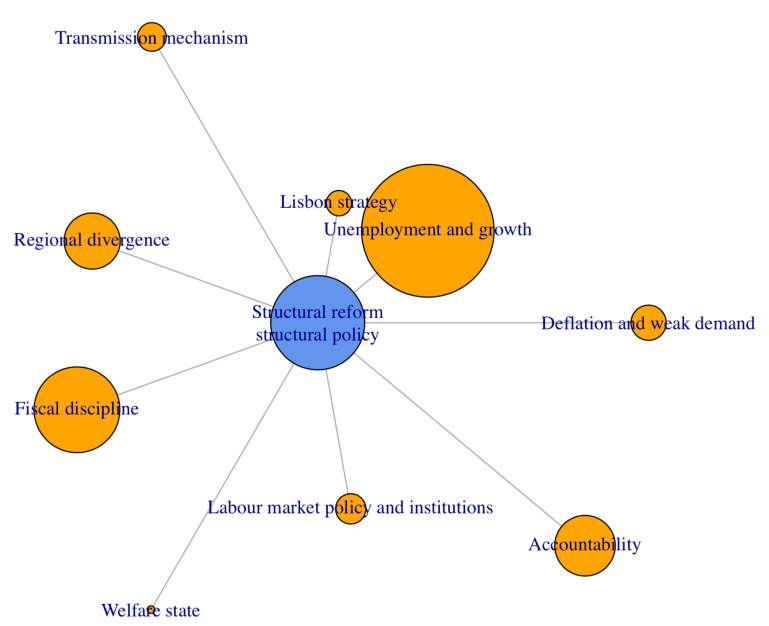

(a) $1999-2004$

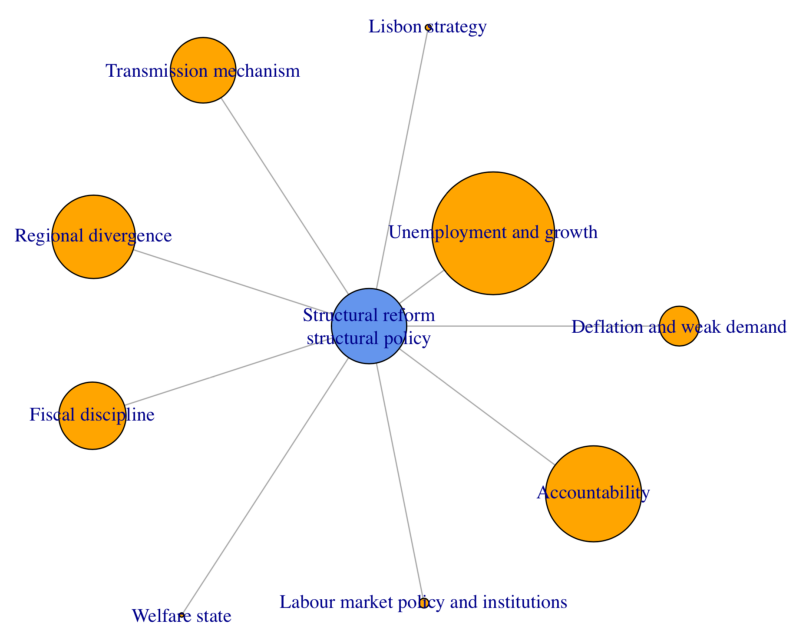

(c) $2010-2015$

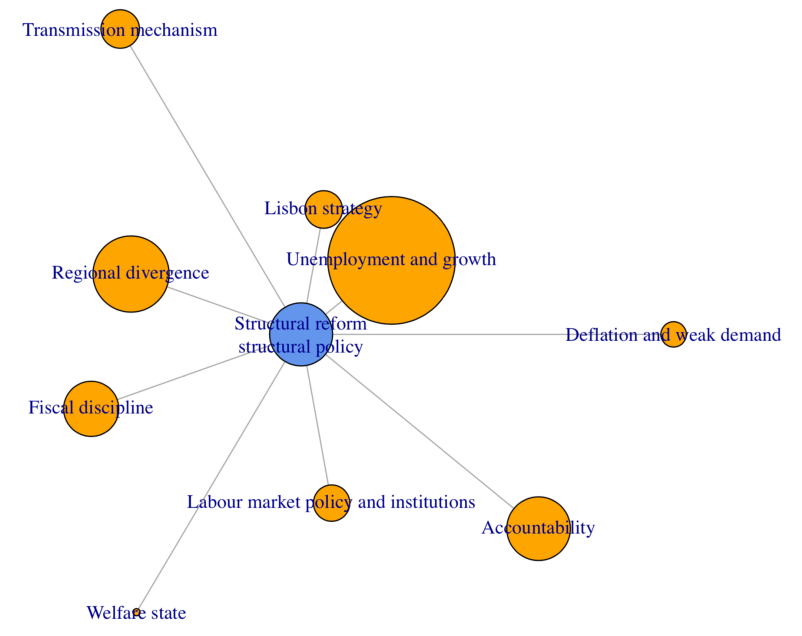

(b) 2005-2009

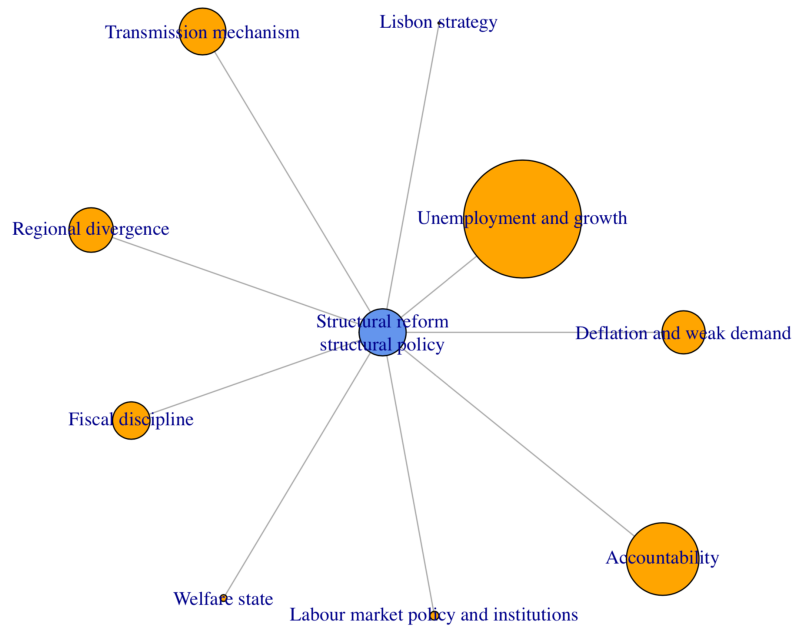

(d) 2016-2019

Note: Length of link measures 1-cosine distance, size of node indicates relative dictionary frequency. 
Table A.7: Manually created dictionaries for collocations.

\begin{tabular}{|c|c|c|c|c|}
\hline Deflation and weak demand & Unemployment and growth & Lisbon strategy & Transmission mechanism & Regional divergence \\
\hline $\begin{array}{l}\text { deflation } \\
\text { deflationary } \\
\text { disinflation } \\
\text { disinflationary } \\
\text { secular stagnation } \\
\text { lack demand } \\
\text { demand side } \\
\text { demand deficient } \\
\text { weak aggregate }\end{array}$ & $\begin{array}{l}\text { unemployment } \\
\text { employment } \\
\text { growth } \\
\text { job creation }\end{array}$ & Lisbon & $\begin{array}{l}\text { transmission mechanism } \\
\text { transmission channel } \\
\text { transmission monetary } \\
\text { monetary transmission } \\
\text { policy transmission }\end{array}$ & $\begin{array}{l}\text { divergence } \\
\text { unit labour } \\
\text { real exchange } \\
\text { regional asymmetries } \\
\text { regional asymmetry } \\
\text { regional disparities } \\
\text { regional disparity } \\
\text { productivity differences } \\
\text { wage differentiation } \\
\text { competitive } \\
\text { competitiveness }\end{array}$ \\
\hline Fiscal discipline & Welfare state & Labour market policy & Accountability & \\
\hline $\begin{array}{l}\text { public spending } \\
\text { government spending } \\
\text { public expenditure } \\
\text { government expenditure } \\
\text { state expenditure } \\
\text { public deficit } \\
\text { government deficit } \\
\text { state deficit } \\
\text { government budget } \\
\text { state budget } \\
\text { budget deficit } \\
\text { public debt } \\
\text { government debt } \\
\text { state debt } \\
\text { budget discipline } \\
\text { spending discipline } \\
\text { fiscal discipline } \\
\text { growth pact }\end{array}$ & $\begin{array}{l}\text { welfare state } \\
\text { social welfare } \\
\text { social contribution } \\
\text { social protection } \\
\text { unemployment protection } \\
\text { unemployment compensation } \\
\text { unemployment benefit } \\
\text { pension contribution } \\
\text { retirement contribution }\end{array}$ & $\begin{array}{l}\text { trade union } \\
\text { employment protection } \\
\text { job protection } \\
\text { against dismissal } \\
\text { flexible hour } \\
\text { short-term contract } \\
\text { flexible labour } \\
\text { flexible contract } \\
\text { social partner } \\
\text { framework agreement } \\
\text { collective agreement } \\
\text { collective bargaining } \\
\text { sectoral bargaining } \\
\text { centralized bargaining } \\
\text { wage setting } \\
\text { wage indexation }\end{array}$ & $\begin{array}{l}\text { accountable } \\
\text { accountability } \\
\text { legitimate } \\
\text { legitimacy } \\
\text { mandate }\end{array}$ & \\
\hline
\end{tabular}




\section{Appendix B. Quotes from ECB speeches addressing structural reforms, 1999- 2019}

Table B.8: Period I: 1999-2004

\begin{tabular}{|c|c|c|c|}
\hline No. & Date & Speaker & Quotes \\
\hline 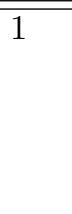 & 14/1/1999 & Duisenberg & $\begin{array}{l}\text { Appropriate fiscal policies and structural reforms implemented by national } \\
\text { governments are vital and considerable progress is required in these areas. } \\
\text { Moreover, continued wage moderation in both the public and private sectors } \\
\text { would contribute to reducing the unacceptably high level of unemployment } \\
\text { in many parts of the euro area. }\end{array}$ \\
\hline 2 & $8 / 3 / 1999$ & Noyer & $\begin{array}{l}\text { Appropriate structural reforms implemented by national governments are } \\
\text { of the utmost importance. Much progress is required in this broad area. } \\
\text { Moreover, responsible wage settlements in both the public and private sec- } \\
\text { tors are necessary to reduce the unacceptably high level of unemployment } \\
\text { in many parts of the euro area. }\end{array}$ \\
\hline 3 & $12 / 3 / 1999$ & Duisenberg & $\begin{array}{l}\text { The root causes of high unemployment in the European Union are structural } \\
\text { rigidities in the labour market as well as tax and public transfer policies. } \\
\text { This view is supported by a wide body of academic literature and was also a } \\
\text { key finding of the OECD Jobs Study. It is obvious that structural problems } \\
\text { require structural solutions. ... in Europe there is an urgent need to } \\
\text { improve incentives aimed at getting the long-term unemployed back to work. } \\
\text { It also suggests that there is little scope for a stimulus to increase demand, } \\
\text { but rather that structural measures should be implemented. ....Although } \\
\text { the path of structural reform is not always an easy one, it is the only way } \\
\text { in which we can achieve the lasting reductions in unemployment that are so } \\
\text { urgently required. ... continued wage moderation in both the public and } \\
\text { private sectors would contribute to the reduction of the unacceptably high } \\
\text { level of unemployment in many parts of the euro area. }\end{array}$ \\
\hline 4 & $25 / 3 / 1999$ & Duisenberg & $\begin{array}{l}\text { What is needed appears to be national structural reforms to make sustain- } \\
\text { able reductions in unemployment rather than a boost to euro area aggregate } \\
\text { demand. For example, the Netherlands, Ireland, Portugal, Austria and Lux- } \\
\text { embourg all currently show unemployment rates well below the euro area } \\
\text { average. ...The need for structural reform is widely recognised, for instance } \\
\text { in the OECD Jobs Study and at the November } 1997 \text { Luxembourg European } \\
\text { Council meeting, and some progress with new policy measures is already be- } \\
\text { ing made. }\end{array}$ \\
\hline 5 & $23 / 6 / 1999$ & Noyer & $\begin{array}{l}\text { The root causes of high unemployment in the European Union are structural } \\
\text { rigidities in labour markets as well as tax and public transfer policies. This } \\
\text { view is supported by a wide body of academic literature and was also a } \\
\text { key finding of the OECD Jobs Study. ... Although the path of structural } \\
\text { reform is not always an easy one, it is the only way in which we can achieve } \\
\text { the lasting reductions in unemployment that are so urgently required. Only } \\
\text { structural reforms that aim at stable labour markets where supply and } \\
\text { demand meet in a flexible way will ensure that the benefits of EMU for } \\
\text { economic growth are really achieved. }\end{array}$ \\
\hline 6 & $11 / 10 / 1999$ & Duisenberg & $\begin{array}{l}\text { The ECB will continue to cajole governments into implementing necessary } \\
\text { structural reforms, but the final hard decisions - and I recognise that they } \\
\text { are hard decisions, since the considerable benefits of structural reform only } \\
\text { become apparent with time - lie with the national authorities. }\end{array}$ \\
\hline
\end{tabular}




\begin{tabular}{|c|c|c|c|}
\hline 7 & $26 / 10 / 1999$ & Duisenberg & $\begin{array}{l}\text { While the contribution it makes through maintaining price stability must } \\
\text { not be overlooked, monetary policy clearly cannot solve the serious struc- } \\
\text { tural unemployment problem in the euro area. Other policy areas have } \\
\text { the instruments needed and are thus responsible for solving the structural } \\
\text { problems. ... structural reforms in labour and goods markets, as well as } \\
\text { a moderate development of wage costs, can best address the root causes of } \\
\text { currently high unemployment in Europe. ... the debate on a "balanced } \\
\text { and appropriate policy mix" should not be used to deflect attention from } \\
\text { the structural reforms that are urgently needed to address the euro area's } \\
\text { serious structural unemployment problem. }\end{array}$ \\
\hline 8 & $26 / 10 / 1999$ & Noyer & $\begin{array}{l}\text { Another argument supporting better functioning labour and product mar- } \\
\text { kets is that the monetary policy of the Eurosystem is and can only be geared } \\
\text { to the euro area as a whole. It can thus not take into account purely national } \\
\text { or regional developments. The cyclical positions of participating countries } \\
\text { have not yet completely converged, although - with the single currency in } \\
\text { place - some national differences may disappear over time. This requires } \\
\text { national policies and labour and good markets to be increasingly flexible in } \\
\text { order to be able to respond effectively to economic shocks that can affect } \\
\text { any monetary union. }\end{array}$ \\
\hline 9 & $16 / 10 / 2000$ & Hämäläinen & $\begin{array}{l}\text { The single currency has been an important catalyst in stimulating the struc- } \\
\text { tural reform process. Certainly, we are only at the beginning of the process } \\
\text { and much more needs to be done, but I am encouraged by the fact that } \\
\text { there seems to be wider and wider support and understanding of the need } \\
\text { for structural changes. }\end{array}$ \\
\hline 10 & $6 / 4 / 2001$ & Trichet & $\begin{array}{l}\text { The Euro is, per se, also a strong catalyst for structural reforms in all non- } \\
\text { financial domains in Europe: a single currency facilitates the full comparison } \\
\text { of prices, taxes and earnings. I think that the euro could encourage "cross- } \\
\text { fertilisation" of best practice through stronger co-ordination of Member } \\
\text { States' structural policies in areas such as labour markets, education and } \\
\text { training, job creation incentives, effective welfare safety nets, etc. }\end{array}$ \\
\hline 11 & $13 / 6 / 2002$ & Duisenberg & $\begin{array}{l}\text { Both high, sustainable economic growth and the ability to adjust smoothly } \\
\text { to changes in the economic environment require further economic integra- } \\
\text { tion and competition. This, in turn, is closely linked to the process of } \\
\text { structural reform, which, to use Schumpeter's words, can be seen as a nec- } \\
\text { essary precondition for a dynamic economic process, a disturbance of the } \\
\text { economic status quo. The introduction of the euro acts as a catalyst for this } \\
\text { dynamic process of structural change. .. Low wage flexibility is also an } \\
\text { important factor behind the lack of price flexibility in the euro area. Many } \\
\text { studies indicate that in comparison with the United States, real wages are } \\
\text { relatively inflexible in Europe. More specifically, I mean that the downward } \\
\text { responsiveness of real wages to the level of unemployment is more limited } \\
\text { in Europe than in the US. There are, however, notable differences across } \\
\text { countries in the euro area. }\end{array}$ \\
\hline
\end{tabular}




\begin{tabular}{|c|c|c|c|}
\hline ...11 & $13 / 6 / 2002$ & Duisenberg & $\begin{array}{l}\text {.. The irrevocable fixing of exchange rates and the introduction of the } \\
\text { single currency may lead to a convergence in the production and export } \\
\text { structures of economies in the euro area, thereby reducing the risk of future } \\
\text { asymmetric shocks. This argument is often referred to as the "endogeneity" } \\
\text { of the optimal currency area hypothesis. Hence, according to the endogene- } \\
\text { ity literature, the euro area could gradually become more of an optimal } \\
\text { currency area, after the introduction of the euro. More generally, it has to } \\
\text { be borne in mind that all empirical studies on whether the countries that } \\
\text { have entered the euro area constitute an optimal currency area are based } \\
\text { on historical data. These data refer to regimes with flexible or fixed-but- } \\
\text { adjustable exchange rates. In short, the regime shift to a monetary union } \\
\text { may have an impact on economic structures and may alter some of the } \\
\text { conclusions drawn on the basis of these historical data. ... In addition to } \\
\text { government policies, there are signs of a gradual change in labour market } \\
\text { behaviour related to the wage formation process. Discipline seems to have } \\
\text { improved in that field over the past decade. Such a change, resulting from } \\
\text { lower inflation expectations, is important. Furthermore, there seems to be } \\
\text { a growing awareness that, in a single currency environment, the price in- } \\
\text { creases and loss of competitiveness generated by excessive wage settlements } \\
\text { cannot be compensated by an exchange rate depreciation and may directly } \\
\text { result in a loss of jobs. }\end{array}$ \\
\hline 12 & $29 / 4 / 2003$ & Papademos & $\begin{array}{l}\text { One of the main messages of } 2002 \text { has been that the euro area economy needs } \\
\text { to become more flexible and that, to this end, structural reforms need to be } \\
\text { stepped up, notably in labour and product markets. Only decisive action } \\
\text { to implement structural reforms can make the euro area a more dynamic } \\
\text { economy and raise the welfare of its citizens. }\end{array}$ \\
\hline 13 & $9 / 5 / 2003$ & Duisenberg & $\begin{array}{l}\text { the introduction of the euro has illustrated the need for more co-ordinated } \\
\text { efforts in the European Union. I refer in particular to an increased need } \\
\text { to enhance the co-ordination of structural policies in Europe, i.e. policies } \\
\text { which aim to improve the functioning of market mechanisms and the op- } \\
\text { eration of the economy as a whole. In my view, there are three reasons } \\
\text { why such enhanced co-ordination of structural policies is necessary. First, } \\
\text { the introduction of the euro has made exchange rate fluctuations obsolete } \\
\text { as an instrument of adjustment. For instance, before the establishment of } \\
\text { Economic and Monetary Union (EMU), divergent national economic devel- } \\
\text { opments could be addressed by a depreciation or appreciation of national } \\
\text { currencies. ...to enhance economic adjustment via wages and prices so that } \\
\text { it is comparable to the level of adjustment existing between regions of the } \\
\text { United States, policies aiming at increasing the flexibility of the markets } \\
\text { are necessary. ... Mr. President, I sincerely hope - both in my capacity } \\
\text { as President of the ECB and as a European citizen and staunch supporter } \\
\text { of European integration - that the introduction of the euro will act as a } \\
\text { catalyst for increased co-ordination in the area of structural policies. And, } \\
\text { as I already mentioned, I hope the euro will also perform this function in } \\
\text { other areas. }\end{array}$ \\
\hline
\end{tabular}




\begin{tabular}{|c|c|c|c|}
\hline 14 & $5 / 9 / 2003$ & Duisenberg & $\begin{array}{l}\text { By being strictly geared towards maintaining price stability in a credible } \\
\text { and lasting manner, monetary policy makes an important contribution to } \\
\text { achieving a high level of output and employment, and to sustaining growth. } \\
\text { Confidence in lasting price stability removes the inflation risk premium on } \\
\text { interest rates, ensuring low real interest rates, which in turn foster invest- } \\
\text { ment, growth and employment. Theoretical and empirical evidence clearly } \\
\text { confirm that there is no long-term trade off between price stability and } \\
\text { economic growth. Trying to use monetary policy to fine-tune economic ac- } \\
\text { tivity or to gear it above a sustainable level will, in the long run, simply } \\
\text { lead to rising inflation - not to faster economic growth. Structural reforms } \\
\text { in the labour and goods markets are a key element of any long-term strat- } \\
\text { egy to improve investment, growth and employment prospects. First, more } \\
\text { flexible markets increase the speed with which countries can adapt to eco- } \\
\text { nomic shocks, thereby speeding up economic recovery. Second, increased } \\
\text { competition in labour and product markets is conducive to a high level of } \\
\text { innovation and the rapid spread of technological progress. This in turn } \\
\text { supports long-term growth, without contributing to inflationary tendencies. } \\
\text { Third, structural reform may facilitate the transmission of monetary policy. } \\
\text { In more rigid economies, interest rate changes are transmitted to prices after } \\
\text { a longer delay, and structural barriers can prevent the economic efficiency } \\
\text { gains of the primary objective of monetary policy - price stability - from } \\
\text { being fully realised. }\end{array}$ \\
\hline 15 & $29 / 11 / 2003$ & Trichet & $\begin{array}{l}\text { More than ever there is in Europe a need to push ahead with structural } \\
\text { reforms for enhancing the competitiveness of the euro area. Structural re- } \\
\text { forms in the labour and product markets, and in social security systems, } \\
\text { are needed to allow a more flexible allocation and utilisation of capital and } \\
\text { human resources, thereby enhancing the euro area's growth potential and } \\
\text { facilitating the adjustment to economic shocks. The Governing Council } \\
\text { very strongly supports recent and ongoing efforts by a number of govern- } \\
\text { ments in this direction and also encourages social partners to fully commit } \\
\text { themselves to the objective of making the euro area a more dynamic and } \\
\text { innovative economy as called for by the "Lisbon agenda", which was agreed } \\
\text { upon by the European Council in } 2000 \text {. Sound supply-side policies should } \\
\text { aim to increase the flexibility of the labour markets, reducing the disincen- } \\
\text { tives to work. Such policies would enhance confidence that working hard } \\
\text { and undertaking new investments in human and physical capital will not } \\
\text { be penalised through costly rigidities. Entrepreneurs and international in- } \\
\text { vestors would invest more in equipment and research in the euro area and } \\
\text { offer new jobs. Such a reform agenda would enhance supply-side dynamics } \\
\text { and thus potential output growth in many ways. ...You may ask what all } \\
\text { this has to do with monetary policy. First, as the central bank responsible } \\
\text { for the euro area, we place great value on seeing a major necessary condition } \\
\text { for growth, job creation and prosperity for current and future generations } \\
\text { being fulfilled: ensuring price stability, confidence in the euro and its pur- } \\
\text { chasing power is our own decisive contribution to sustainable growth. And } \\
\text { this contribution is less difficult to deliver in an environment where gov- } \\
\text { ernments and social partners contribute to confidence and potential output } \\
\text { growth. }\end{array}$ \\
\hline 16 & $26 / 1 / 2004$ & Trichet & $\begin{array}{l}\text { More specifically, [labour market] policies should aim at: ... Allowing } \\
\text { for a sufficient degree of wage differentiation to ensure that wages reflect } \\
\text { divergent productivity growth and regional/sectoral developments. }\end{array}$ \\
\hline
\end{tabular}




\begin{tabular}{|c|c|c|c|}
\hline 17 & $20 / 4 / 2004$ & Trichet & 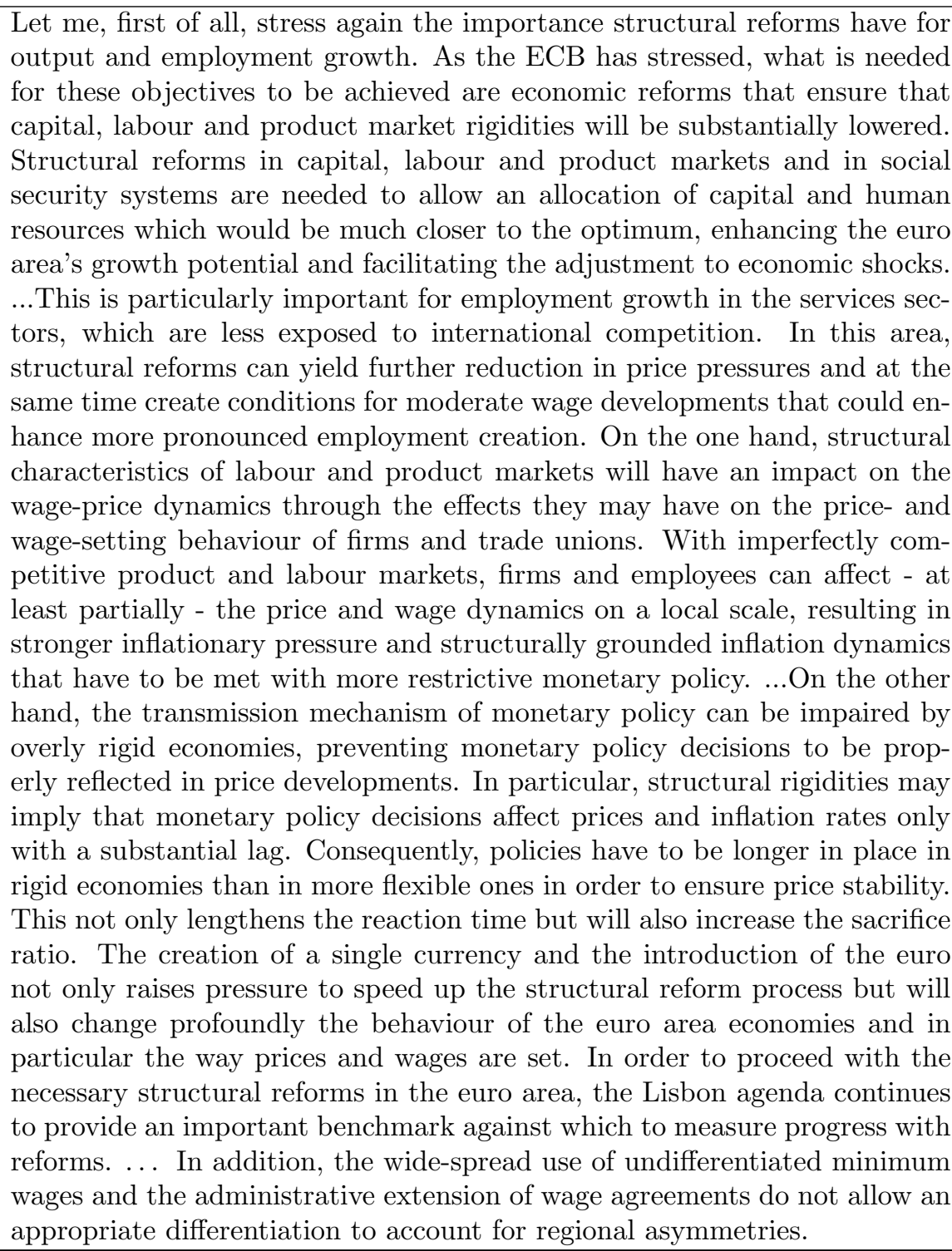 \\
\hline 18 & $23 / 4 / 2004$ & Trichet & $\begin{array}{l}\text { Thus far, progress with the implementation of labour market reforms has } \\
\text { been uneven in the euro area. ...In many countries, it is important to } \\
\text { enhance the flexibility of labour contracts and wage-setting to enhance em- } \\
\text { ployment growth in a lasting manner. ... Reforms are also needed that } \\
\text { allow wages to reflect more strongly regional and sectoral productivity dif- } \\
\text { ferences. }\end{array}$ \\
\hline 19 & $13 / 5 / 2004$ & Trichet & $\begin{array}{l}\text { Let me mention some of the objectives at the top of the reform lists where } \\
\text { I think progress is most needed. As far as the labour market is concerned, } \\
\text { moderation in wage agreements is essential, not only in order to contain } \\
\text { risks to price stability but also to foster employment growth and to enhance } \\
\text { competitiveness. Wage bargaining outcomes should allow for appropriate } \\
\text { wage developments in the overall economy, as well as a sufficient degree of } \\
\text { wage differentiation to reflect more strongly regional and sectoral produc- } \\
\text { tivity differences. }\end{array}$ \\
\hline
\end{tabular}




\begin{tabular}{|l|l|l|l|}
\hline 20 & $28 / 5 / 2004$ & Issing & $\begin{array}{l}\text { The ECB has always stressed the importance of a swift implementation } \\
\text { of structural reform agendas across the euro area. This reflects above all } \\
\text { the firm belief that structural reforms enhance the welfare of the European } \\
\text { citizens. But structural reforms also tend to facilitate monetary policy and } \\
\text { increase its effectiveness. A more flexible economic environment helps the } \\
\text { labour and product markets to better adjust to economic shocks and respond } \\
\text { to policy actions more quickly. For example, more flexible labour markets } \\
\text { may imply that negative supply shocks are absorbed with a smaller short- } \\
\text { term increase in inflationary pressures, as second round effects are more } \\
\text { subdued. This, in turn, allows monetary policy to react less strongly. Such } \\
\text { an environment will not only make it easier for monetary policy to maintain } \\
\text { price stability, but it will also help to keep the volatility of inflation and } \\
\text { output lower. }\end{array}$ \\
\hline
\end{tabular}




\begin{tabular}{|c|c|c|c|}
\hline No. & Date & Speaker & Quotes \\
\hline 21 & $18 / 10 / 2005$ & Trichet & $\begin{array}{l}\text { Although the structural reforms have been moving in the right direction, } \\
\text { they have not been far reaching enough. In fact, we need to step up con- } \\
\text { siderably the implementation of the necessary reforms in order to achieve } \\
\text { the Lisbon goals. In particular more progress in labour market reforms is } \\
\text { needed to attract more people into labour market and investment in research } \\
\text { and development and human capital should be strongly encouraged. What } \\
\text { needs to be done is rather clear. But how to deliver it in an environment } \\
\text { of rapid change is the more challenging question. . . regarding the insuf- } \\
\text { ficiently clear commitment, the Heads of State or Government also clearly } \\
\text { set out the responsibilities of the European and the national level. Since } \\
\text { the Member States are responsible for most of the policy reforms required } \\
\text { for achieving the Lisbon objectives, they have now been called upon to take } \\
\text { full national ownership of the Strategy. }\end{array}$ \\
\hline 22 & $6 / 2 / 2006$ & Trichet & $\begin{array}{l}\text { Let me be somewhat more specific about the areas in labour and product } \\
\text { markets where I think that further progress is most urgently needed. Struc- } \\
\text { tural reforms are crucial in the areas of employment protection legislation } \\
\text { and wage-setting mechanisms, including wage indexation. A sufficient de- } \\
\text { gree of wage differentiation is important to ensure that wage adjustments } \\
\text { closely reflect regional and sectoral productivity differences. }\end{array}$ \\
\hline 23 & $24 / 3 / 2006$ & Issing & $\begin{array}{l}\text { In other words, to quote Rose and Frankel: "countries which join EMU, } \\
\text { no matter what their motivation may be, may satisfy OCA properties ex- } \\
\text { post even if they do not ex-ante!" This has been termed the "endogeneity } \\
\text { of optimum currency area" effect. Several authors have brought forward } \\
\text { concepts similar to the above hypothesis of the "endogeneity of OCA", but } \\
\text { in areas other than trade. Artis and Zhang have discussed the endogeneity } \\
\text { of symmetry of shocks. Blanchard and Wolfers, and Saint Paul and Bento- } \\
\text { lila, have discussed the endogeneity of labour market institutions. Kalemli- } \\
\text { Ozcan, Sørensen and Yosha discuss the effects of sharing a single currency } \\
\text { on financial markets and insurance schemes. Therefore, there may be di- } \\
\text { verse sources of "endogeneities of OCA." Such endogeneities can be seen } \\
\text { as a set of processes triggered by the start of a monetary union. Hence, } \\
\text { monetary union may help to set in motion forces bringing countries closer } \\
\text { together, forces that were not present (or strong enough) before. }\end{array}$ \\
\hline 24 & $24 / 04 / 2006$ & Trichet & $\begin{array}{l}\text { The lack of sufficient structural reform in Europe is, in my view, a major } \\
\text { cause of the gap in economic growth between Europe and the US. ... the } \\
\text { ECB's monetary policy has a role to play in supporting the implementation } \\
\text { of structural reforms. A credible monetary policy aimed at maintaining } \\
\text { price stability in the medium term and solidly anchoring medium and long } \\
\text { term inflation expectations contributes decisively to a stable economic envi- } \\
\text { ronment. In a stable macroeconomic context, it is not only easier to single } \\
\text { out where reforms are needed, but the benefits of reforms are also made } \\
\text { more visible and convincing, thus supporting their acceptance. }\end{array}$ \\
\hline 25 & $29 / 6 / 2006$ & Trichet & $\begin{array}{l}\text {...the persistence of growth and inflation differentials also show that some } \\
\text { other sources of diversity are not economically justified. They might be } \\
\text { partly attributable to insufficient flexibility; in such economies corrections } \\
\text { must be made. For example, in some economies the combination of weak } \\
\text { labour productivity growth and of strong nominal increases of wages and } \\
\text { salaries for a sustained period might lead to a progressive deterioration of } \\
\text { their competitiveness. Furthermore, in several euro area countries there } \\
\text { exists specificities in wage formation (for example due to indexation mech- } \\
\text { anisms or due to the influence of the public sector) and in price formation } \\
\text { in general. This limits the responsiveness to shocks. }\end{array}$ \\
\hline
\end{tabular}




\begin{tabular}{|c|c|c|c|}
\hline 26 & $13 / 06 / 2007$ & Trichet & $\begin{array}{l}\ldots \text { the creation of the euro area - like globalisation - highlights the need for } \\
\text { flexible economies. I do not see this as a negative aspect. On the contrary, } \\
\text { it is a positive implication. In this sense, EMU has increased the pressure } \\
\text { on all policy-makers and also all social partners [...]. They must ensure a } \\
\text { well-functioning euro area, by good management aimed at enhanced flexibil- } \\
\text { ity, integrated labour, product and financial markets and disciplined fiscal } \\
\text { policies. ... Needless to say, the responsibility for the implementation of } \\
\text { reforms is in the hands of national governments, of Parliaments and of so- } \\
\text { cial partners. We know very well that structural reforms may face both } \\
\text { resistance from economic agents and different sensitivities in public opin- } \\
\text { ion. This is why it is extremely important to communicate the fact that } \\
\text { the medium to long-term benefits of structural reforms will significantly } \\
\text { outweigh any short-term cost. We therefore strongly support governments } \\
\text { in their implementation of structural reforms and we consider our duty to } \\
\text { stress and explain their benefits. What factors may help to increase flexibil- } \\
\text { ity within the euro area? Economic flexibility can be promoted by removing } \\
\text { the institutional barriers to flexible wage and price-setting mechanisms. If } \\
\text { wages and prices are flexible enough and be able to adjust to the changes in } \\
\text { the economic conditions, then this will help to avoid unwelcome fluctuations } \\
\text { in unemployment. Specifically, in a monetary union most of the adjustment } \\
\text { has to take place through national labour markets. }\end{array}$ \\
\hline 27 & $21 / 9 / 2007$ & Trichet & $\begin{array}{l}\text { Economic flexibility can be promoted by removing the institutional barriers } \\
\text { to flexible wage and price-setting mechanisms. Specifically, in a monetary } \\
\text { union, most of the adjustment has to take place through national labour } \\
\text { markets. Therefore, wage setting should appropriately reflect the different } \\
\text { situations of sectors, of firms and of overall labour market conditions. Let } \\
\text { me stress that social partners share responsibility for ensuring that wage } \\
\text { settlements fully take into account the need to reduce unemployment and } \\
\text { to enhance labour market access and employment. Moreover, governments } \\
\text { should also be aware of the way in which wage setting for public servants } \\
\text { can serve as a role model for the private sector. And social partners need } \\
\text { to take into account the different conditions at the firm and sectoral level, } \\
\text { internalising the repercussions of wage settlements on competitiveness and } \\
\text { thus employment at their company and in their industry, sector or region. } \\
\text { Sufficient wage differentiation would improve employment opportunities for } \\
\text { less skilled workers and in regions or sectors with high unemployment. }\end{array}$ \\
\hline 28 & $8 / 10 / 2007$ & Trichet & $\begin{array}{l}\text {...the public sector also functions as a role model, for example as regards } \\
\text { wages or administrative prices. The behaviour of the public sector can, for } \\
\text { instance, make social partners more aware of the trade-off between higher } \\
\text { salaries and job creation. }\end{array}$ \\
\hline 29 & $16 / 5 / 2008$ & Trichet & $\begin{array}{l}\text { The smooth functioning of the euro area, taking into account the relative } \\
\text { importance of the public sector and of the non tradable sector in a number } \\
\text { of economies, calls for not relying exclusively on the working of the com- } \\
\text { petitiveness channel amongst tradable goods and services to engineer cor- } \\
\text { rections of deviations of relative cost competitiveness inside the euro area. } \\
\text { Appropriate handling of the unit labour costs in the civil service and public } \\
\text { sector, appropriate recommendations to social partners given in a timely } \\
\text { manner would avoid in certain cases painful national corrections through } \\
\text { the competitive channel. To sum up, changes in relative cost competitive- } \\
\text { ness provide much more room for manoeuvre than was foreseen prior to the } \\
\text { launch of the euro. In several euro area countries, wage formation is still } \\
\text { linked to indexation mechanisms or is influenced by the public sector. This } \\
\text { limits the ability to respond to shocks. Structural reforms and the liberali- } \\
\text { sation of product and labour markets can and must contribute to significant } \\
\text { increases in flexibility. }\end{array}$ \\
\hline
\end{tabular}




\begin{tabular}{|l|l|l|l|}
\hline 30 & $27 / 10 / 2008$ & Trichet & $\begin{array}{l}\text {..national authorities can make a substantial contribution to more modest } \\
\text { labour cost developments. In particular, the public sector should be a role } \\
\text { model in terms of wage-setting and should not contribute to strong overall } \\
\text { labour cost growth. }\end{array}$ \\
\hline 31 & $23 / 11 / 2009$ & Trichet & $\begin{array}{l}\text { In the future, changes in labour market institutions to make wages adjust } \\
\text { to productivity are essential to repairing past cumulative misalignments. } \\
\text { There is a need for moderation in wage claims to regain competitiveness. } \\
\text { This window of opportunity cannot be missed in those countries where } \\
\text { substantial increases of production costs have been one of the causes for } \\
\text { widening imbalances in current accounts, and Spain is one of them. }\end{array}$ \\
\hline
\end{tabular}




\begin{tabular}{|c|c|c|c|}
\hline No. & Date & Speaker & Quotes \\
\hline 32 & $7 / 10 / 2010$ & Constâncio & $\begin{array}{l}\text { Concerning the third challenge, creating the conditions for growth, the G20 } \\
\text { have approved the Framework for Strong, Sustained and Balanced Growth } \\
\text { which, alongside a set of structural reforms, has at its core fiscal consoli- } \\
\text { dation, which could lead to 1) internal rebalancing in advanced economies } \\
\text { by substituting public stimuli for increased private demand; and 2) exter- } \\
\text { nal rebalancing by promoting domestic demand in surplus countries and } \\
\text { increasing external demand in deficit countries ...the EU-level targets under } \\
\text { the Europe } 2020 \text { strategy are being translated into precise country-specific } \\
\text { targets to guide policy-making at the national level. ... structural reforms } \\
\text { should be introduced to increase wage flexibility and the adjustment of } \\
\text { wages to appropriate levels. This could be achieved through measures to } \\
\text { improve the functioning of labour markets, which would also facilitate the } \\
\text { necessary transfer of workers from the non-traded to the traded sectors. } \\
\text { In fact, we have already seen wagesetting developments in some European } \\
\text { countries that many observers would have believed impossible just a few } \\
\text { years ago. The adoption of measures to increase productivity growth is also } \\
\text { essential. }\end{array}$ \\
\hline 33 & $12 / 10 / 2011$ & Stark & $\begin{array}{l}\text { Some countries have built up significant internal and external economic im- } \\
\text { balances during the past decade, and recorded inflation rates persistently } \\
\text { above the euro area average. The ECB repeatedly warned against emerging } \\
\text { imbalances. Increases in labour compensation in some countries, driven in } \\
\text { most cases by high public sector wage increases, exceeded productivity gains } \\
\text { by a significant margin, leading to increases in unit labour costs in excess } \\
\text { of the euro area average and a gradual erosion of competitiveness. Let me } \\
\text { stress that governments and social partners share responsibility for ensur- } \\
\text { ing that wage determination sufficiently takes into account labour market } \\
\text { conditions and does not jeopardise competitiveness and employment. Gov- } \\
\text { ernments should also be aware that wage setting in the public sector can } \\
\text { serve as a role model for the private sector. ...in the absence of nominal } \\
\text { exchange rate flexibility, any real exchange rate adjustment had to be de- } \\
\text { livered via cuts in wage costs and prices combined with enhancements in } \\
\text { labour productivity. The adjustment in wages was both market-driven, ow- } \\
\text { ing to a sharp decline in the demand for labour, and supported by policies } \\
\text { aimed at cutting public sector wage costs. The labour market adjustment } \\
\text { was not only achieved through wage cuts, but also through employment } \\
\text { cuts, reductions in hours worked and a restructuring of production pro- } \\
\text { cesses. As a result, unit labour costs declined significantly, partly offsetting } \\
\text { their previous excessive gains. }\end{array}$ \\
\hline
\end{tabular}




\begin{tabular}{|c|c|c|c|}
\hline 34 & $7 / 2 / 2014$ & Mersch & $\begin{array}{l}\text { Put simply, there is no way we can achieve higher potential growth in the } \\
\text { euro area without them. Structural reforms are essential to raise the trend } \\
\text { components of the inputs to production (investment and labour) and the } \\
\text { efficiency with which they are used (total factor productivity). ... These } \\
\text { may seem like theoretical arguments. Yet Ireland is a very concrete working } \\
\text { example. Thanks to prior structural reforms, relative prices in this country } \\
\text { adjusted almost immediately after the } 2008-09 \text { recession, allowing the econ- } \\
\text { omy to quickly begin regaining its competitiveness. The unemployment rate } \\
\text { started declining in 2012, falling from } 14 \% \text { in December that year to } 12 \% \\
\text { a year later. By contrast, in other programme countries with less flexible } \\
\text { economies the recovery started much later. ... Since the } 1990 \text { s we have } \\
\text { known that supply conditions in the euro area needed to be reformed. This } \\
\text { was the aim of the failed Lisbon Agenda. And indeed, it was the context } \\
\text { for a famous quote about the apparent inconsistency between reform and } \\
\text { re-election. What is new today, however, is the urgency for action. We } \\
\text { are facing the risk of a structural set back in growth. We can therefore no } \\
\text { longer afford to delay, nor should we over-burden monetary policy. Struc- } \\
\text { tural reforms are a must. }\end{array}$ \\
\hline 35 & $19 / 2 / 2014$ & Praet & $\begin{array}{l}\text { A key complement to fiscal adjustment has therefore been structural re- } \\
\text { form. In several countries a series of bold structural reforms have been } \\
\text { implemented. In Portugal in particular, the reform agenda has been broad- } \\
\text { based and far-reaching. It has included public administration, health and } \\
\text { pension systems, education, judicial systems, competition frameworks, in- } \\
\text { dustrial relations, labour markets, energy markets, network industries, ser- } \\
\text { vices sectors and regulated professions Over time the economic and social } \\
\text { pay-offs of reforms will be high, in terms of higher wealth and employment. } \\
\ldots \text { It is therefore crucial that the reform process is strengthened in all euro } \\
\text { area countries, also those not affected by the crisis. }\end{array}$ \\
\hline 36 & $9 / 7 / 2014$ & Draghi & $\begin{array}{l}\text { I believe that the case for community-level governance does not apply only to } \\
\text { fiscal policy, or to the banking union, but also to structural reforms ...struc- } \\
\text { tural reforms play a crucial role - and perhaps an even more important role } \\
\text { in the euro area than in other unions. Markets can be opened through EU } \\
\text { legislation. But it is only through structural reforms that firms and indi- } \\
\text { viduals can be enabled to take full advantage of that openness. ...over the } \\
\text { past few years, we have seen both the risks associated with insufficient com- } \\
\text { petitiveness in some Member States and the benefit of structural reforms. } \\
\text { We have witnessed the accumulation of external imbalances in peripheral } \\
\text { economies prior to the crisis, and how that left them vulnerable to "sudden } \\
\text { stop" dynamics. And more recently, we have seen the improvement that } \\
\text { has taken place when governments implemented reform. }\end{array}$ \\
\hline
\end{tabular}




\begin{tabular}{|c|c|c|c|}
\hline ...36 & $9 / 7 / 2014$ & Draghi & $\begin{array}{l}\text {...In fact, the return of market confidence in the euro area results mainly } \\
\text { from the acknowledgement that individual governments, in particular in } \\
\text { some of the most stressed countries, have taken significant corrective ac- } \\
\text { tion and will continue to do so where needed. So while lack of reform can } \\
\text { threaten the cohesion of the Union, we can already see how decisive reform } \\
\text { can strengthen it. But we are only at the beginning. The final judgment } \\
\text { now rests on our being able to show that cohesion also produces growth and } \\
\text { jobs. The second reason why a stronger role for the Union could be bene- } \\
\text { ficial is that, similar to fiscal policies, establishing rules at the level of the } \\
\text { Union may in fact help national authorities implement reform. Structural } \\
\text { reforms reach deep enough into societal arrangements and practices that } \\
\text { they can only succeed if they are made the object of strong domestic owner- } \\
\text { ship. At the same time, those reforms require substantial political capital. } \\
\text { Historical experience, for example of the IMF, makes a convincing case that } \\
\text { the discipline imposed by supranational bodies can make it easier to frame } \\
\text { the debate on reforms at the national level. In particular, the debate can be } \\
\text { framed not in terms of whether, but in terms of how reform needs to take } \\
\text { place. In other words, I am not convinced by the argument that, in terms } \\
\text { of structural reforms, there is an opposition between rules and ownership. } \\
\text { On the contrary, they can be mutually reinforcing. }\end{array}$ \\
\hline 37 & $17 / 10 / 2014$ & Cœuré & $\begin{array}{l}\text { Reforms can be shown to produce two, opposing sets of forces in the short- } \\
\text { term. One is contractionary, as reforms lead to lower prices and higher real } \\
\text { interest rates. If monetary policy is at the zero lower bound and unable } \\
\text { to respond and fiscal space has been exhausted, higher real rates cause the } \\
\text { private sector to postpone consumption and investment decisions and GDP } \\
\text { to contract. ... I see a need today to rebalance our focus: to focus less on } \\
\text { achieving internal devaluation, and more on raising productivity. And this } \\
\text { entails a broader set of reforms than countries have adopted thus far ... } \\
\text { reforms are a necessary but not a sufficient condition for growth ... Today } \\
\text { the reform agenda facing European countries is largely about productivity, } \\
\text { and this means that pursuing reforms aggressively is less likely to have } \\
\text { negative short-term effects. Many of the reforms that lead to downward } \\
\text { price pressures and higher real interest rates have already been done, and } \\
\text { their effects are working their way through the economy now. The remaining } \\
\text { reforms are more about boosting investment demand and productivity and } \\
\text { so raising growth today. }\end{array}$ \\
\hline 38 & $27 / 11 / 2014$ & Draghi & $\begin{array}{l}\text { Lack of structural reforms raises the spectre of permanent economic diver- } \\
\text { gence between members. And insofar as this threatens the essential cohe- } \\
\text { sion of the Union, this has potentially damaging consequences for all EMU } \\
\text { members. Seen from this perspective, euro area countries cannot be agnos- } \\
\text { tic about whether and how others address their reform challenges. Their } \\
\text { own prosperity ultimately depends on each country putting itself in a posi- } \\
\text { tion to thrive within the Union. And for this reason, there is a strong case } \\
\text { for sovereignty over relevant economic policies to be exercised jointly. That } \\
\text { means above all structural reforms. ... over the longer-term, acknowledg- } \\
\text { ing the community of interest and the reality of spillovers in the form of a } \\
\text { real sharing of sovereignty in the governance of structural reforms. }\end{array}$ \\
\hline
\end{tabular}




\begin{tabular}{|c|c|c|c|}
\hline No. & Date & Speaker & Quotes \\
\hline 39 & $02 / 02 / 2015$ & Coeuré & $\begin{array}{l}\text { The conclusion, therefore, is that constantly tinkering with our common } \\
\text { fiscal rules while leaving governance of structural policies entirely at the na- } \\
\text { tional level makes little sense. If fiscal policies are to be freed from structural } \\
\text { dominance, then we need an equally strong framework in both domains. ... } \\
\text { The only way to resolve this paradox is if, behind the "veil of ignorance", } \\
\text { risk-sharing is symmetric between countries. This is only possible if all coun- } \\
\text { tries share sovereignty over structural reforms so that they have equivalent } \\
\text { growth prospects and shock absorption capacity. ... I am of course aware } \\
\text { that structural reforms can have mixed effects on growth and inflation, and } \\
\text { in certain situations can impact negatively on both in the short-term. But } \\
\text { empirical evidence is mixed and the balance of effects depends crucially on } \\
\text { designing reform packages well. }\end{array}$ \\
\hline 40 & $22 / 5 / 2015$ & Draghi & $\begin{array}{l}\text { If we talk often about structural reforms it is because we know that our abil- } \\
\text { ity to bring about a lasting return of stability and prosperity does not rely } \\
\text { only on cyclical policies - including monetary policy - but also on structural } \\
\text { policies. The two are heavily interdependent. . . . accommodative mone- } \\
\text { tary policy supports structural reform by ensuring that the investment and } \\
\text { employment benefits materialise faster. And structural reform, by reducing } \\
\text { uncertainty about the future macro- and microeconomic outlook, supports } \\
\text { monetary policy by releasing the pent-up investment demand that accom- } \\
\text { modative policy creates. }\end{array}$ \\
\hline 41 & $15 / 6 / 2015$ & Praet & $\begin{array}{l}\text { But the key point is about diversity. It is not enough to give one-dimensional } \\
\text { prescriptions such as that the all labour markets must become more flexible. } \\
\text { What matters is that the combination of policies and institutions within } \\
\text { each country produces an outcome that is satisfactory for its citizens and } \\
\text { sustainable for the euro area as a whole. . . . There are some minimum } \\
\text { requirements that come with being part of a monetary union. But there are } \\
\text { various ways of meeting them. This is perhaps a notion that, in the future, } \\
\text { we could do a better job of conveying. }\end{array}$ \\
\hline 42 & $17 / 6 / 2016$ & Coeuré & $\begin{array}{l}\text { I agree that central bankers should tread very cautiously in other economic } \\
\text { policy areas. But monetary policy, and particularly so in a monetary union, } \\
\text { does not operate in a vacuum. Although central bankers take their decisions } \\
\text { independently, they also have to take into account what other parties are } \\
\text { doing. ... there are at least three reasons why central bankers cannot be } \\
\text { indifferent to structural reforms. First, the combination of low potential } \\
\text { growth and the debt overhang inherited from the crisis threatens the Eu- } \\
\text { ropean social contract, a contract that was established in the post-war era } \\
\text { and that was fair and affordable at that time. This in turn is a threat to } \\
\text { the sustainability of our social market economy, which is the environment in } \\
\text { which our monetary policy operates. Second, factor reallocation over time } \\
\text { and across sectors is necessary in order to adjust to shocks and therefore } \\
\text { key to the smooth transmission of monetary policy. And third, convergence } \\
\text { between economies is both an economic and political prerequisite for a well- } \\
\text { functioning monetary union. ... for structural reforms to successfully lift } \\
\text { potential growth in a monetary union, they have to fulfil two important } \\
\text { criteria: (i) they need to be comprehensive and well sequenced and (ii) } \\
\text { all-encompassing. "Comprehensive" means that a narrow focus on labour } \\
\text { market reforms is not sufficient. Structural reforms are also about incen- } \\
\text { tivising innovation, competition and fighting rent-seeking and monopolistic } \\
\text { structures. }\end{array}$ \\
\hline
\end{tabular}




\begin{tabular}{|c|c|c|c|}
\hline \begin{tabular}{ll|}
$\ldots 42$ \\
\end{tabular} & $17 / 6 / 2016$ & Cœuré & $\begin{array}{l}\text { Labour market reforms should be sequenced carefully, in such a way that } \\
\text { a negative short-term effect on employment is ideally felt only when the } \\
\text { recovery is gaining momentum. This could in practice mean that employ- } \\
\text { ment protection is liberalised only when reforms to increase nominal wage } \\
\text { flexibility have been carried out. This can have a quick effect on reducing } \\
\text { unemployment even shortly after its implementation. Second, active labour } \\
\text { market policies can help to reallocate workers across sectors of the econ- } \\
\text { omy while an adjustment is taking place. Third, expansionary fiscal and } \\
\text { monetary policy can also dampen the negative short-term impact of labour } \\
\text { market reforms. The current low interest rate environment and the mildly } \\
\text { expansionary fiscal stance on aggregate in the euro area provide a good op- } \\
\text { portunity for governments to minimise the short-run costs of labour market } \\
\text { reforms. }\end{array}$ \\
\hline 43 & $13 / 4 / 2016$ & Constâncio & $\begin{array}{l}\ldots \text { structural reforms entail short-term contractionary effects many times. } \\
\text { Eggertsson, Ferrero and Raffo (2014) highlight that such contractionary } \\
\text { short-term effects are amplified at the LB, because they cannot be off-set } \\
\text { by expansionary monetary policy through a reduction in interest rates. A } \\
\text { recent IMF working paper by Bordon, Ebeke and Shirono (2016) concludes } \\
\text { that "Existing studies have shown that the long-run effects of structural } \\
\text { reforms on growth and employment are positive. However, the evidence on } \\
\text { the short-run effects of structural reforms is rather mixed and limited." The } \\
\text { recently published April } 2016 \text { IMF WEO agrees and writes: "... reforms } \\
\text { to employment protection arrangements and unemployment benefit systems } \\
\text { have positive effects in good times, but can become contractionary in pe- } \\
\text { riods of slack. These results suggest the need for carefully prioritizing and } \\
\text { sequencing reforms." ... the effects of structural reforms are contingent on } \\
\text { the state of the cycle and the degree of slack in the economy as well as on } \\
\text { the accompanying stance of macroeconomic policies. }\end{array}$ \\
\hline 44 & $30 / 11 / 2016$ & Draghi & $\begin{array}{l}\text { Structural reforms are therefore urgently needed to raise productivity } \\
\text { growth and unlock unused labour potential and thereby avoid stagnation in } \\
\text { per capita income. ... There are benefits for fiscal policy too. By lifting } \\
\text { output and employment and lowering unemployment, reforms improve gov- } \\
\text { ernments' structural balances. Moreover, higher levels of potential output } \\
\text { reduce the current overhang of public sector debt that is impinging on some } \\
\text { countries' ability to carry out stabilisation policies. The greater fiscal space } \\
\text { also enables governments to redistribute the benefits of reforms across the } \\
\text { whole population. Some reforms can have upfront negative distributional } \\
\text { effects, which governments may want to offset. }\end{array}$ \\
\hline 45 & $18 / 10 / 2017$ & Draghi & $\begin{array}{l}\text { During the crisis, because of powerful vested interests, labour market re- } \\
\text { forms were not accompanied by product market reforms in some countries, } \\
\text { and so wages fell and prices did not adjust in tandem. ... the case for } \\
\text { structural reforms needs to go beyond their efficiency benefits. We need to } \\
\text { show that reforms can contribute to both efficiency and equity. One way } \\
\text { this can be achieved is by focusing more on reforms with positive distri- } \\
\text { butional effects. ... some reforms will always have negative distributional } \\
\text { effects, at least in the short term. But in these cases we can do more to } \\
\text { reduce inequality by ensuring that flexibility is combined with security. In- } \\
\text { clusive labour markets are ones with well-functioning active labour market } \\
\text { policies that allow people to reskill, and proactive macroeconomic policies } \\
\text { that shorten job transitions. Before the crisis, several countries introduced } \\
\text { labour market reforms to increase flexibility, but did little to make their } \\
\text { labour markets more secure. This ended up disproportionately penalising } \\
\text { young people, who had weak job protections and meagre support during } \\
\text { unemployment. }\end{array}$ \\
\hline
\end{tabular}




\begin{tabular}{|c|c|c|c|}
\hline 46 & $30 / 11 / 2017$ & Praet & $\begin{array}{l}\text { Reforms which improve economic structures make countries more resilient } \\
\text { and the single monetary policy more effective. In good times, reforms tend } \\
\text { to face strong opposition, which only breaks down during times of economic } \\
\text { demise, either following a long period of economic decline or in the wake of } \\
\text { a severe crisis. Evidence of crisis-led reforms is plentiful: for instance, not } \\
\text { just the Latin American trade reforms in the } 1980 \text { s and 1990s, but also the } \\
\text { most recent experience in the euro area goes in this direction. The long- } \\
\text { run benefits of reforms are largely undisputed, but the potential short-term } \\
\text { costs have increasingly been highlighted. Such undesirable effects can ma- } \\
\text { terialise through a number of channels. Reforms that enhance competition } \\
\text { can displace workers and capital in the short run. In bad economic times, } \\
\text { there is a risk that these factors of production will not be absorbed by new } \\
\text { entrants, thereby aggravating the recession. Reforms that lower wages can } \\
\text { depress consumer demand in the short term if not rapidly offset by employ- } \\
\text { ment gains and the prospect of future productivity related income gains that } \\
\text { would materialise in normal times. To ensure that the expansionary effect } \\
\text { of reforms dominates in the short run, both the sequencing of reforms and } \\
\text { the policy mix matter. ... may be better if product market reforms precede } \\
\text { labour market reforms and if product market reforms focus on reducing en- } \\
\text { try barriers in service sectors with large pent-up demand. As regards the } \\
\text { policy mix, if there is fiscal space, IMF research has underscored the bene- } \\
\text { ficial effects of carefully designed fiscal packages which can overcompensate } \\
\text { for the short-run cost of reforms. }\end{array}$ \\
\hline 47 & $19 / 6 / 2018$ & Draghi & $\begin{array}{l}\text { annual growth in negotiated wages has also started to move upwards. Look- } \\
\text { ing ahead, recent wage agreements notably in Germany, but also in other } \\
\text { large countries such as France and Spain, point to a continuation of these } \\
\text { wages dynamics. There are signs that the restraint in public-sector wage } \\
\text { growth, which had in the past dragged on aggregate wage growth, is starting } \\
\text { to relax. }\end{array}$ \\
\hline 48 & $29 / 3 / 2019$ & Couré & $\begin{array}{l}\text { Although pre-crisis policy advice strongly focused on reducing nominal and } \\
\text { real rigidities in product and labour markets, today there are still signifi- } \\
\text { cant differences across countries in the response to common euro area-wide } \\
\text { shocks. ... The upshot is that, in this environment, monetary policy is } \\
\text { more difficult to calibrate. Different transmission mechanisms propagate } \\
\text { the same shock to different degrees and with lags that may vary across } \\
\text { countries. Minimising these differences in transmission does not require all } \\
\text { countries to adopt the same economic structures. What matters is for coun- } \\
\text { tries to have institutions that deliver the right outcomes, both individually } \\
\text { and jointly. Our system of economic coordination, the European Semester, } \\
\text { still falls short of achieving this objective. And as a consequence, it still } \\
\text { falls short of supporting adequately the single monetary policy. ... Hetero- } \\
\text { geneity is part of the euro area's DNA. It is a source of strength, provided } \\
\text { our institutions and markets have the instruments and ability to effectively } \\
\text { absorb idiosyncratic shocks. }\end{array}$ \\
\hline
\end{tabular}




\section{Appendix C. List of interviews}

\begin{tabular}{llll}
\hline No. & Role & Date of interview & Communication \\
\hline 1 & Former member of the ECB Executive Board & $11 / 18 / 2020$ & Video call \\
2 & Former member of the ECB Executive Board & $11 / 19 / 2020$ & Video call \\
3 & Former member of the ECB Executive Board & $11 / 27 / 2020$ & Video call \\
4 & Former member of the ECB Executive Board & $12 / 14 / 2020$ & Video call \\
5 & Former member-state finance minister & $03 / 05 / 2021$ & In person \\
\hline
\end{tabular}

